\title{
THE EDWARD STEICHEN NAVAL AVIATION PHOTOGRAPHIC UNIT COLLECTION AT THE HARRY RANSOM CENTER
}

\author{
by \\ Kate Kaluzny, BA, \\ University of Wisconsin-Madison, 2001 \\ A thesis presented to \\ Ryerson University \\ in partial fulfillment of the \\ requirements for the degree of \\ Master of Arts in the program of \\ Photographic Preservation and Collections Management
}

Austin, Texas, USA 2016

(C) Kate Kaluzny 2016 
I hereby declare that I am the sole author of this thesis. This is a true copy of the thesis, including any required final revisions, as accepted by my examiners.

I authorize Ryerson University and The Harry Ransom Center to lend this thesis to other institutions or individuals for the purpose of scholarly research.

I further authorize Ryerson University and The Harry Ransom Center to reproduce this thesis by photocopying or by other means, in total or in part, at the request of other institutions or individuals for the purpose of scholarly research.

I understand that my thesis may be made electronically available to the public.

\section{Kate Kaluzny}




\section{The Edward Steichen Naval Aviation Photographic Unit Collection at The Harry Ransom Center Master of Arts, 2016 \\ Kathryn Kaluzny \\ Photographic Preservation and Collections Management Ryerson University}

\section{Abstract}

This applied thesis project is based on a collection of 172 gelatin silver photographs taken by Edward Steichen's Naval Aviation Photographic Unit during World War II. The Harry Ransom Center in Austin, Texas was one of twelve institutions that received photographs from Edward Steichen's personal collection upon his death in 1973. The prints in the collection depict scenes from some of the most intense fighting in the Pacific. The unit, led by Steichen throughout the war, came to be known as the preeminent combat photography unit in the Navy.

My final thesis includes the following components: an analytical paper detailing the history of the unit and discussing the scope and significance of the collection; an outline of the digitization and housing processes; a Filemaker Pro database for the collection; and content generated for the Ransom Center's Digital Collections page, scheduled for upload in late summer or early fall 2016. 


\section{Acknowledgements}

Above all, I would like to thank Jessica McDonald for giving me the idea in the first place, and generously allowing me the time, resources, and support to pursue it.

I am immensely grateful to Don Snyder both for his excellent feedback and enthusiasm for the topic.

Thank you to Stephen Jareckie for kindly allowing me to use his notes from the survey he did on the collection back in 1996.

Thanks to Bob Burley for acting as my second reader.

A huge THANK YOU to my family for their tremendous support while I worked on my project.

And finally, much love and thanks to my good friend and fellow student Jamie Sheppard, who endured endless ranting, venting, and panicking from me throughout the process with aplomb. 


\section{Table of Contents}

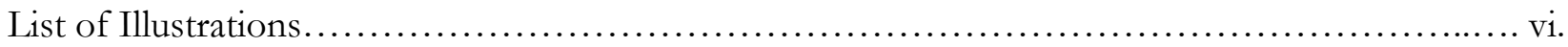

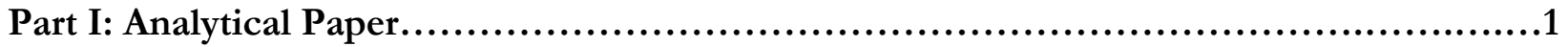

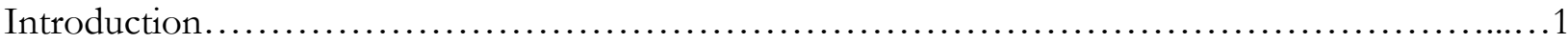

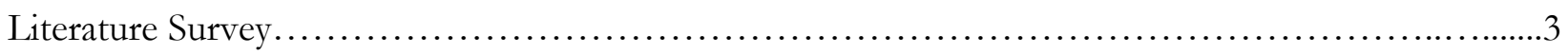

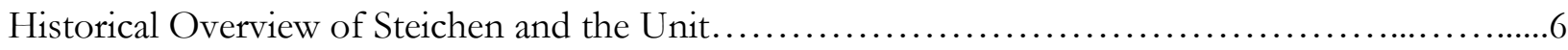

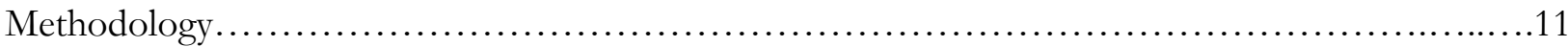

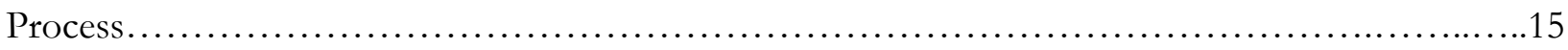

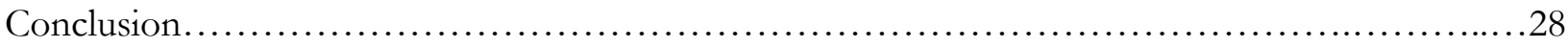

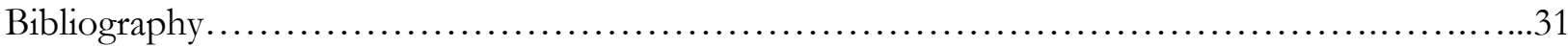

Appendix A: Selected Photographs from the Collection.............................. 33

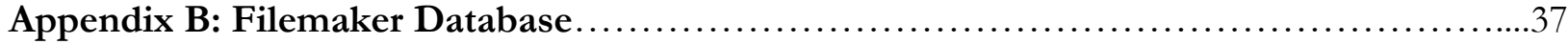

Appendix C: Collection Description for the Ransom Center's Digital Collections Page.........38 


\section{List of Illustrations}

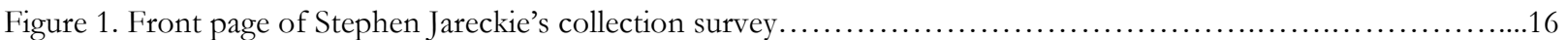

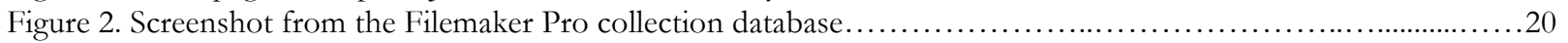

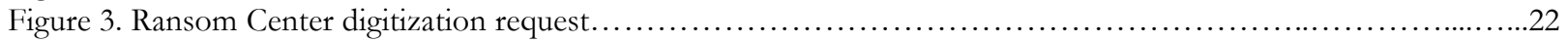

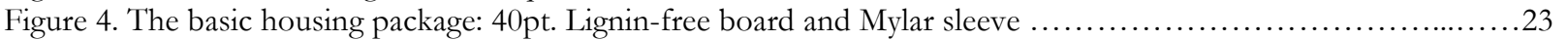

Figure 5. The print is centered on the board first, then slid into the Mylar sleeve.................................23

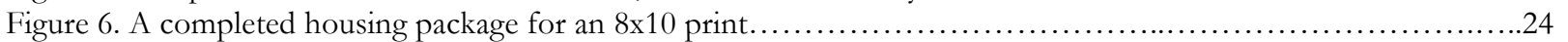

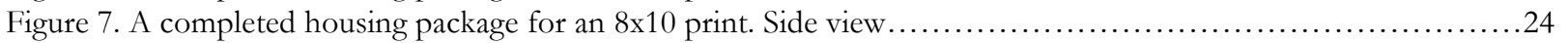

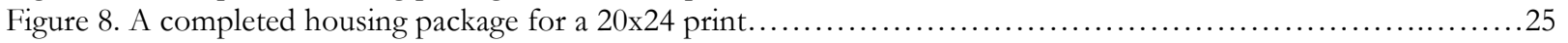

Figure 9. The Julia Margaret Cameron Photography Collection page on the Ransom Center's Digital

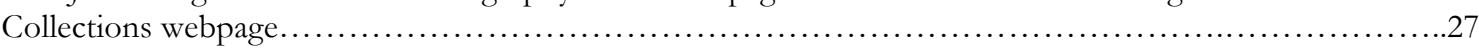

Figure 10. Description information: The detail fields will be imported from my Filemaker Pro database and appear

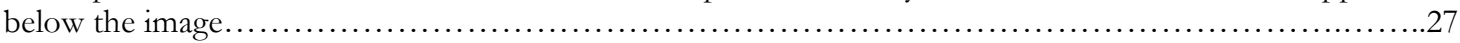

Figure 11. Image detail: The ability to zoom in closely on a high resolution image will be useful for researchers in

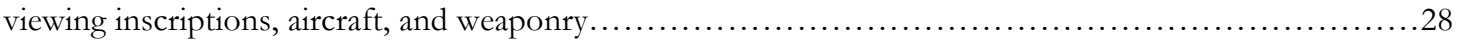

Figure 12. Photographer unknown, Last Rites Aboard the USS Franklin, 1945, Gelatin silver print, $27.2 \times 34.2 \mathrm{~cm}$, Edward Steichen Naval Aviation Photographic Unit Collection, 974:0255:0168...........................34

Figure 13. Photographer unknown, [LCI rocket attack], 1944, Gelatin silver print, 27.1 x $34.4 \mathrm{~cm}$, Edward Steichen Naval Aviation Photographic Unit Collection, 974:0255:0134..........................34

Figure 14. Photographer unknown, U-Boat Sailors Cringe from Depth Bomb, 1943, Gelatin silver print, 27.3 x $34.3 \mathrm{~cm}$, Edward Steichen Naval Aviation Photographic Unit Collection, 974:0255:0069..........................35

Figure 15. Horace Bristol, Gareloi Volcano, 1943, Gelatin silver print, 49.8 x $59.5 \mathrm{~cm}$, Edward Steichen Naval

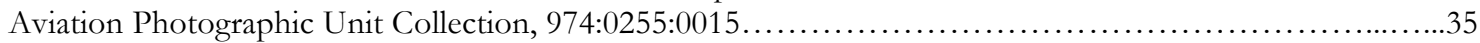

Figure 16. Horace Bristol, Angry Avengers, 1943, Gelatin silver print, 59.4 x 49.8 cm, Edward Steichen Naval

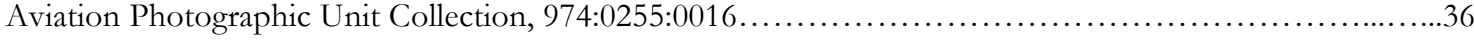

Figure 17. Edward Steichen, [Battleships from above], 1943-1945, Gelatin silver print, 49.9 x $59.9 \mathrm{~cm}$, Edward Steichen Naval Aviation Photographic Unit Collection, 974:0255:0118.........................36

Figure 18. Paul Dorsey, Tarawa, 1943, Gelatin silver print, 27.3 x 34.3 cm, Edward Steichen Naval Aviation

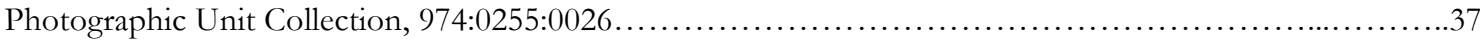

Figure 19. Horace Bristol, Homeward Bound, 1943, Gelatin silver print, 59.9 x $49.5 \mathrm{~cm}$, Edward Steichen Naval Aviation Photographic Unit Collection, 974:0255:0019 


\section{Part I: Analytical Paper}

\section{Introduction}

The Harry Ransom Center at The University of Texas at Austin is a research library and museum containing extensive manuscript, film, photography, and performing arts collections. The photography collection consists of over five million prints and negatives, forty thousand books and journals, and cameras and photographic ephemera from the nineteenth and twentieth centuries. With the acquisition of the Gernsheim Collection in 1963 came an impressive assemblage of documents and objects chronicling the origins and evolution of the photographic medium and consequently, the Ransom Center has become a world-renowned destination for photographic research. Continuing this tradition, I had the privilege to do my master's thesis project working in its first-rate photography collection. When I first wrote to Jessica McDonald, the Chief Curator of Photography, regarding my residency there, she provided me with an outline of possible projects that I could be working on and the section on Edward Steichen's U.S. Naval Aviation Photographic Unit collection immediately intrigued me due to my long-standing fascination with war photography. This collection comprises 172 gelatin silver prints taken by the Naval Aviation Photographic Unit during World War II, under Edward Steichen's leadership.

According to a letter from Tom Maloney recently discovered by McDonald, Maloney distributed, at Joanna Steichen's request, Steichen's personal collection of eight thousand naval photographs to the following twelve institutions upon his death, though it is unclear how these twelve were chosen: the U.S. Naval Academy Museum, the U.S. Navy Museum, the U.S. Military Academy Museum, the U.S. Air Force Academy Museum, the U.S. Marine Corps Museum, the U.S. Coast Guard Museum, the U.S. Naval Base in San Diego, The Naval War College, the Museum of Modern Art, George Eastman House, the Stevens Institute of Technology, and the University of Texas at Austin. The Ransom Center received the collection in January 1974, but due to 
limited personnel, resources, and a backlog characteristic of major research archives, it remained unaccessioned and un-cataloged. With Jessica McDonald's permission and guidance, I chose this project as my practical thesis, to include the following components: a historical overview of the Naval Aviation Photographic Unit, a Filemaker Pro cataloging database, new housings for the prints, and the generation of content for the Ransom Center's Digital Collections page, scheduled to be uploaded in late summer or early fall 2016.

The Naval Aviation Photographic Unit, assembled and led by Edward Steichen, was commissioned by the U.S. Navy's Bureau of Aeronautics in 1942 to take photographs for the purposes of recruitment and training. However, under Steichen's guidance, the unit progressively took on more of a documentary role in the war and it came to be acknowledged as the preeminent combat documentation unit in the Navy, producing some of the most compelling imagery from the war in the Pacific. The unit's photographs continue to be historically significant as intimate visual documents of Navy life, and as examples of war propaganda illustrating how context and intent influence interpretation as well as what they reveal about the cultural values of the time. ${ }^{1}$

Also, the influence they had on the post-war careers of the unit photographers, including that of Steichen himself, makes them all the more significant. While the two largest repositories for the collection, the National Archives and Records Administration and the United States Naval Academy, have made many of the unit's images accessible on their websites, these only account for around ten percent of the estimated fifteen thousand total images taken by the unit. ${ }^{2}$ Thus, the collection presents a unique opportunity to provide access for researchers in the fields of World War II and photography, and potentially even make a contribution to World War II scholarship.

${ }^{1}$ Caroline Brothers, War and Photography: a Cultural History (New York: Routledge, 1997), 2.

${ }^{2}$ Christopher Phillips, Steichen at War (New York: H.N. Abrams, 1981), 7. 


\section{Diterature Survey}

For my thesis, I have chosen a practical project consisting of the research, cataloging, coordinating digitization, re-housing, and the generation of content for a searchable online collection for the 172 photographs from The Edward Steichen Naval Aviation Photographic Unit Collection at the Ransom Center. The photographs taken by the unit are historically significant visual documents, as they were the first photographs to portray all facets of sailors' daily lives in the Pacific theatre during World War II. Accordingly, the goals for my thesis project are to make these images accessible in a way that foregrounds their historical significance and fosters a more comprehensive and compelling view of the war in the Pacific, while at the same time promoting an awareness and appreciation of the unit photographers who took them. I have structured my literature survey to start with literature on the history of the unit in order to better comprehend the collection's scope and context. Next, I discuss literature that specifically applies to the digitization, housing, and web accessibility for images.

My research began with an overview of photography's historic role within the U.S. Navy. Mame Warren, author and editor at the Marshall Foundation in Lexington, Virginia, details the growing recognition of photography's potential usefulness to the naval war effort in her article, "Focal Point of the Fleet: U.S. Navy Photographic Activities in World War II" (2005), from The Journal of Military History. This realization culminated in expanded resources and facilities allocated for the use of photography in World War II. Warren also discusses how Steichen's team differed from other naval photographers in that the men on his team were ranked as officers, allowed to carry their own equipment, and had their film developed in a separate processing center supervised by Steichen himself. ${ }^{3}$

Next, I directed my research specifically to Edward Steichen and the photographers of the unit. I began with Steichen's autobiography A Life in Photography (1963) for his personal perspective on war and his

\footnotetext{
3 Mame Warren, "Focal Point of the Fleet: U.S. Navy Photographic Activities in World War II," The Journal of Military History 69, no. 4 (2005): 1045-1079.
} 
motivation for becoming involved in World War II. Faces of War: the Untold Story of Edward Steichen's WWII Photographers (2009) by Mark D. Faram, a writer/photographer for the Navy Times and a Navy veteran, was extremely valuable for its insight into Steichen's involvement with the unit and for biographical information about its photographers. Faram discusses the profound effect the FSA photographs had on Steichen in the 1930s, which illustrated to him the photograph's emotive power for the viewer. Another source that details Edward Steichen's drive to photograph the war is "Edward Steichen Goes to War" (2008), an article published in Aviation History Magazine by writer/editor Nan Siegel, which shed light specifically on Steichen's growing appreciation for photography's ability to effect social change, quoting Steichen at one point: "I believe [photography] is potentially the best medium for explaining man to himself and to his fellow man."4 Moreover, it details the unit's origins and how it transitioned to more of a documentary role under Steichen's leadership. Photography historian Christopher Phillips' book Steichen at War (1981) provides a visual survey of the unit's best-known photographs. In addition, each image in this book is credited to its individual photographer instead of to the U.S. Navy, as the latter practice was standard procedure at the time they were taken. ${ }^{5}$

I accessed a copy of The Museum of Modern Art's catalog from Steichen's exhibition, Power in the Pacific, for a glimpse of the photographs' visual arrangement within the exhibition space, and the strategic arrangement of the text-image dynamic in a narrative progression constructed to have maximum emotional impact on the viewer. This catalog also provided insight into the propaganda uses of the photographs as visual testaments to naval strength. For a more in-depth examination of how photographs were used as propaganda in Steichen's exhibitions at MoMA, I turned to Jorge Ribalta's Public Photographic Spaces: Exbibitions of Propaganda, from Pressa to The Family of Man, 1928-55, which provided valuable analysis of Steichen's shows Road to Victory, Power in the Pacific, and The Family of Man exhibitions. Finally, to see how the unit's work has impacted post-World War II

\footnotetext{
${ }^{4}$ Nan Siegel, "Edward Steichen Goes to War." Aviation History 18, no. 3 (2008): 42. http://ezproxy.lib.ryerson.ca/login?url=http://search.proquest.com/docview/219838289?accountid=13631

${ }^{5}$ Mark Faram, Faces of War: the Untold Story of Edward Steichen's WWII photographers (New York: Berkley Caliber, 2009$), 91$.
} 
conflict imagery, I read War/Photography: Images of Armed Conflict and Its Aftermath by Anne Tucker, Curator Emerita at the Museum of Fine Arts, Houston, which accompanied the 2012 exhibition by the same name. Ransom Center procedure dictated that the digitization of the collection would be undertaken in-house by Pete Smith, Photographer in the Digitization Lab. To organize the collection for digitization, I found Bülow and Ahmon's Preparing Collections for Digitization and Ritzenthaler and Connor's Photographs: Archival Care and Management helpful for tips on how to organize collections efficiently for a speedy digital workflow.

Regarding the print re-housing component, I looked to Bernard Lavédrine’s book Photographs of the Past: Process and Preservation (2009) for a review of recommended materials for photographic storage, specifically for what types of paper should be used and what plastic materials to avoid in the housing and storage of photographs. ${ }^{6}$ Upon viewing the collection and after consulting with Photograph Conservators Barbara Brown and Diana Diaz Canas and Chief Curator of Photography Jessica McDonald, we decided on the following course of action for all of the print sizes: place the prints flat on 40 point lignin-free board, enclose them in Mylar sleeves, and store in drop front boxes.

The final component of my project is to create the content for a searchable online digital collection to be placed online via the Ransom Center's CONTENTdm system, the digital content management system that the Ransom Center uses to put all their collections online. The Edward Steichen Naval Aviation Photographic Unit collection is scheduled to go up on the Ransom Center's digital collections webpage in late summer 2016.

The fundamental goal for this project is to provide accessibility to the collection. By doing so, I hope to expose a new segment of the population to the unit's work, inspire new scholarship on the photographs, and help position the unit more prominently within the contextual narrative of World War II photography.

\footnotetext{
${ }^{6}$ Bernard Lavédrine, Photographs of the Past: Process and Preservation (Los Angeles, California: Getty Conservation Institute, 2009), 285-289.
} 


\section{Wistorical Overview of Steichen and the Unit}

Shortly after Steichen abruptly retired from commercial photography in 1938, he attended the International Photographic Exposition in New York, at that time the largest exhibition of photographs in one place in the city's history. It was here that Steichen would view the Farm Security Administration (FSA) photographs for the first time, and this proved to have a profound and lasting effect on him. ${ }^{7}$ This was the first time he had seen a series of related images convey the human experience in such an authentic and powerful way. ${ }^{8}$ The immediate emotional effect the FSA images had on viewers was remarkable to Steichen and was a galvanizing force for him to create a body of work that had the same emotional resonance.

Steichen volunteered for military service at sixty-two years old and was rejected several times because of his age as well as a more general skepticism about his usefulness to the war effort. Prior to World War II, the Navy's principal use for photography was technical, primarily related to reconnaissance; unlike the longstanding documentation of the Army's actions by its Signal Corps, the Navy had no such tradition. ${ }^{9}$ Steichen contended that photography could be utilized to portray the drama and heroism of the naval side of the war, for use in public relations and recruitment. Privately though, Steichen sought to use this opportunity to build a team committed to creating a photographic record of the war and documenting the human drama of conflict for the American public. ${ }^{10}$ Finally, due to a combination of persistence and powerful connections, he was finally able to convince Captain A.W. Radford of the U.S. Navy to allow him to build a team of photographers to document naval aviation's role in the war. ${ }^{11}$ Steichen's first act was to curate an exhibition at MoMA, commissioned by the U.S. government's Office of Emergency Management, which depicted the country's

\footnotetext{
7 Phillips, Steichen at War, 16-17.

${ }^{8}$ Jorge Ribalta, Public Photographic Spaces: Exbibitions of Propaganda, from Pressa to The Family of Man, $1928-55$ (Barcelona: Museu D'Art Contemporani De Barcelona, 2008), 475.

${ }_{9}^{9}$ Warren, "Focal Point of the Fleet," 1050.

${ }^{10}$ Edward Steichen, A Life in Photography (Garden City, New York: Doubleday \& Company, Inc., 1963$), 12$

11 Ibid.
} 
military strength and the resiliency of the American people. ${ }^{12}$ The exhibition, called Road to Victory, contained 150 photographs of America in times of war and of peace, nearly a third of which came from the FSA. ${ }^{13}$ The show featured what would come to be hallmarks of Steichen's future exhibitions - enlarged images combined with text, hung at dramatic angles, having the effect of leading the viewer through the show as through a narrative. ${ }^{14}$ Road to Victory was hugely successful and according to friends, Steichen claimed that he "got more satisfaction from doing it than from any commercial job he had ever done."

When the United States entered World War II, the Navy soon realized that in order to fight the Japanese in the Pacific, they would need to recruit upwards of thirty thousand fighter pilots. ${ }^{16}$ To that end, Edward Steichen was commissioned to lead the Naval Aviation Photographic Unit in 1942, with the explicit directive to take photographs for recruitment purposes. Steichen selected photographers for his team who had experience in a variety of fields such as advertising, illustration, film, and magazine work, with the express goal of creating a diverse and multifaceted view of life in the Navy. ${ }^{17}$ The photographers chosen for the unit included Horace Bristol, Paul Dorsey, Barrett Gallagher, Alfonso Ianelli, Charles Fenno Jacobs, Victor Jorgensen, Charles Kerlee, Dwight Long, and Wayne Miller; in fact, all of these photographers, with the exception of Dwight Long (who primarily shot films), are represented in the Ransom Center's collection.

Photographs from the unit were published in Life and U.S. Camera magazines and used to illustrate books about the war, such as Carrier War and The Blue Ghost, Steichen's personal account of his time on the USS Lexington. When Steichen began to assemble his team, he sought men who were already experienced photographers from a variety of disciplines in order to obtain imagery with a diversity of perspectives. Horace Bristol and Charles Fenno Jacobs were experienced photojournalists, Charles Kerlee came from a commercial

\footnotetext{
12 Warren, "Focal Point of the Fleet," 1061.

13 Phillips, Steichen at War, 18.

${ }^{14}$ Ribalta, Public Photographic Spaces, 25.

15 Warren, "Focal Point of the Fleet," 1061.

${ }^{16}$ Dave Bradford, "Naval Aviation News," http:// navalaviationnews.navylive.dodlive.mil/. Naval Aviation News. February 24, 2014.

17 Mark Faram, Faces of War, 36.
} 
illustration and advertising background, and Wayne Miller and Victor Jorgensen were younger and less experienced in the field.

The same skill sets that had brought Steichen so much success as a photographer in fine art, advertising, fashion and portraiture were precisely what made him the ideal leader and mentor for the unit. Steichen's experience had given him a wealth of technical and creative expertise in creating an aesthetically pleasing photograph, and had trained his eye to spot images that would be the most compelling and persuasive to the viewer. In addition, his portrait work had established him as a master of capturing the spirit of his subjects with an uncommon empathy and authenticity. This emphasis on photographing the individual was conveyed to Steichen's men as well - according to unit photographer Wayne Miller, Steichen's directions to his photographers in the field were to "bring back something that will please the brass a little bit...spend the rest of your time photographing the man, the little guy; the struggle, the heartaches, plus the dreams of this guy. Photograph the sailor." "Another key point is how Steichen's role also brought out his nascent curatorial drive, which came to the fore in his Road to Victory exhibition and persisted throughout the war in his selection and release of individual images for publication. Steichen would go on after the war to hold the position of Director of the Photography Department at MoMA for fifteen years, during which he curated more than fortyfour shows. By far the most influential and successful of these was The Family of Man in 1955, which he considered "the most important undertaking of my career. In a way, it had its genesis in the several war exhibitions I had organized."19 Steichen used his connections in the publishing world to get the unit's photographs featured prominently in the biggest magazines of the day - Life, Look, the New York. Times Magazine, Popular Photography, Vogue, and U.S. Camera. ${ }^{20}$

Biographies of the most active photographers in the Naval Aviation Photographic Unit are listed below.

\footnotetext{
18 Siegel, "Edward Steichen Goes to War," 42.

${ }^{19}$ Ribalta, Public Photographic Spaces, 461.

${ }^{20}$ Faram, Faces of War, 104-105.
} 
- $\quad$ Horace Bristol - served on the USS Santee (November 1942); USS Ticonderoga (November 1944); USS New Jersey (December 1944); USS Saratoga (1945). Bristol was one of Life's first photographers before the war, and had work published in Time, Fortune, and National Geographic magazines. ${ }^{21}$ After the war, he published numerous books, started the East-West Photo Agency, and was the subject of exhibitions at the J. Paul Getty Museum, Art Center College of Design, and the Los Angeles County Museum of Art.

- $\quad$ Paul Dorsey - served on Tarawa (November 1943) and Guam (July-August 1944). ${ }^{22}$ Dorsey was a professional photography for fifteen years before he joined the unit, taking news and editorial images for The New York Times, Life, and Look. Dorsey was a photographer for the Marines whom Steichen recruited later. ${ }^{23}$ [I was unable to find any information about Dorsey's career after the war.]

- $\quad$ Charles Fenno Jacobs - served on the USS Santee (October-November 1943); USS New Jersey (November-December 1944). He served in the Merchant Marines and was a magazine photographer before the war. ${ }^{24}$ In his work for the unit, his specialty was capturing scenes involving people working with machinery in factories and on battleships. Immediately after the war, Jacobs became a European correspondent for Fortune, covering the German political landscape and life under Communism in Eastern Europe. Jacobs' work was featured in many major exhibitions including Steichen's The Family of Man.

- $\quad$ Victor Jorgensen - served on the USS Lexington (November 1943); USS Monterey (June 1944); USS Solace (March 1945); Philippines (May-June 1945). He was working as a photographer for The Oregonian when World War II broke out and he was recruited for the unit. ${ }^{25}$ He served on the USS Lexington with Steichen and excelled at documenting the daily life of the sailor. Right before the end of the war, he traveled throughout the Philippines, taking documentary photographs of the everyday lives of both soldiers and natives, as well as street scenes, landscapes, and architecture. After the war, Jorgensen worked with his wife as a team, traveling the world and contributing photo stories to Life, Ladies' Home Journal, and Fortune. ${ }^{26}$ Later on, he was president of the American Society of Media Photographers where he fought for fair pay and best practices for photographers.

- Charles Kerlee - served on the USS Suwannee (December 1942); USS Yorktown (June-November 1943); USS Hornet (June 1944). Kerlee was a successful advertising photographer at the time he joined the unit who also possessed a background in motion pictures and commercial illustration. ${ }^{27}$ After the war, he went back to advertising photography and continued to have a successful photography career in New York.

- Wayne Miller - served on the USS Nassau (October 1943), USS Ticonderoga (1944), USS Saratoga (October-December 1943) and on Guam (November 1944). He also photographed the WAVES program (February 1943). Miller started out as the unit's most inexperienced photographer, and went on to be the most successful after the war. ${ }^{28}$ Miller photographed Japanese POWs on Guam and covered the aftermath of Hiroshima. His entire career evinced the same humanism that shaped

\footnotetext{
${ }^{21}$ Ibid., 42-44.

22 Lisle, “The 'Potential Mobilities' of Photography,” http://journal.media-culture.org.au/index.php/mcjournal/ article/view/125.

23 Ibid.

${ }^{24}$ Faram, Faces of War, 39-42.

25 Ibid., 48-50.

${ }^{26}$ Jorgensen, Victor H., Papers. MS 21. Special Collections and Archives, University Library, University of California, Santa Cruz.

27 Ibid., 37-38.

${ }^{28}$ Faram, Faces of War, 30-32.
} 
his work for the unit. Immediately after the war, he won two Guggenheim fellowships for his work on a project called The W ay of Life of the Northern Negro, which documented the African-American population on Chicago's South Side. He also worked alongside Steichen as his associate curator on The Family of Man exhibition at the Museum of Modern Art. He was a member of Magnum and its president from 1962-1966. After his retirement from photography in 1975, he shifted his focus to environmental issues and fought to protect California's forests. ${ }^{29}$

Between the members of the unit, aspects of all the major battles in the Pacific were covered (excepting Pearl Harbor in 1941). The unit's legacy is a standard of excellence in naval photojournalism sustained to this day by a yearlong training program at Syracuse University that teaches sailors photography, writing, and graphic design. ${ }^{30}$

29 "Wayne Miller Biography." Magnum Photos. May 2013. Accessed March 1, 2016.

https://pro.magnumphotos.com/C.aspx?VP3=CMS3\&VF=MAGO31_9_VForm\&ERID=24KL534NBZ.

${ }^{30}$ Ibid., 223. 


\title{
Methodology
}

\author{
Getting Started
}

My first step was to get to know the Ransom Center, become familiar with its layout, procedures, and the people who worked in its various departments. For this reason, I sat down with Jessica McDonald, who was instrumental in helping me work out a plan on how to proceed and introduce me to the people whose assistance I would require in the course of completing my project. She first introduced me to Mary Alice Harper, the Head of Visual Materials Cataloging, whom I would be consulting to create a cataloging database and receive the range of accession numbers for the collection. Next, she briefed Elizabeth Gushee, Librarian, Digital Collections and DAM administration, and Pete Smith, Photographer in the Digital Collections, on the particulars of the project so that they would be able to integrate it into the digitization schedule.

I felt that in order to properly catalog the collection, I needed to begin by researching all I could about the unit's history, its photographers, and its mission during the war. Next, I researched biographical information on Edward Steichen and the unit's photographers. To get a grasp on Steichen's own experience in leading the unit, I read The Blue Ghost, his first-person account of photographing the USS Lexington in 1943. From there, I sought out a compilation of the unit's best photographs grouped by theme and credited to the photographers who took them to get an overall impression of the work. From books published by Steichen and Maloney, I found useful caption, date, and photographer information for many of the photographs. For a historical perspective on the propaganda uses of photography exhibits throughout history, I consulted Jorge Ribalta's book Public Photographic Spaces: Exhibitions of Propaganda, from Pressa to The Family of Man, 1928-55, which deconstructs two of Steichen's most influential exhibitions: Power in the Pacific and The Family of Man, both held at MoMA. Finally, I made a trip to the National Archives site in Maryland in March 2016 to look at the unit's original negatives with the goal of filling in some gaps with regard to subject matter and photographer for several of the images in the Ransom Center's collection. 


\section{Cataloging Database}

After I completed my research, I focused attention on the construction of a Filemaker Pro cataloging database for the collection. In order to accomplish this, I needed to brush up on how to create a database from scratch in the Filemaker program. Although I did a unit on this in my first year Digital Collections Management class, I did not yet feel confident with the program. Therefore I reviewed all my notes from that class and watched numerous tutorials on Lynda.com on creating, populating, and linking information in Filemaker. My next step was to ascertain the image information I needed to include in the database and how that information should be formatted. For this purpose, I consulted first with Jessica McDonald, then with Mary Alice Harper to establish what fields should be present, what cataloging standards the Ransom Center uses, and which controlled vocabularies I need to use to populate certain fields. Afterwards I proceeded to organize and assign accession numbers to the collection from a lot provided by Harper. I arranged the images in a way that I thought would render it the most accessible and intuitive for future researchers; therefore, I settled on an ascending date order, from 1942 to 1945, as this would necessarily keep multiple images from specific locations, ships, and battles together sequentially.

\section{$\underline{\text { Digitization }}$}

In order to prepare for digitizing the collection, I was assisted by several people, both within the photography and digitization departments. First, Jessica McDonald described the details of the project to Elizabeth Gushee, Librarian, Digital Collections and DAM administration, who then gave me a digital projects proposal to fill out. From there, Linda Briscoe Myers, the Assistant Curator of Photography, showed me how to create and submit digitization requests for the images. Due to the fact that the collection is owned by the Ransom Center, procedure dictates that I cannot digitize the items myself. Instead, Pete Smith, Photographer in the Digitization Lab, integrated the collection into his daily workflow and contacted me with any questions 
or issues as they arose. For my part, my responsibilities were to fill out a digital projects proposal form, submit digitization requests for each individual print, and organize the prints for a streamlined workflow.

\section{Housing}

For my own edification and preparation, I felt this was an ideal time to review the types of materials that are recommended for storing photographs; specifically, what types of paper should be used and what plastic materials to avoid. ${ }^{31}$ Jessica McDonald and I reviewed possible housing options recommended for gelatin silver prints based on the print sizes and available storage space. Once I finished assessing the size and condition of the prints as well as the size constraints of the storage space, I consulted with McDonald and Photograph Conservators Barbara Brown and Diana Diaz Canas to determine, based on their expertise, how to house the prints safely while also conserving space. Hence we decided on 40 point lignin-free boards Mylar sleeve enclosures for each of the $11 \times 14,8 \times 10$, and 20x24 prints, and flat storage in a drop front box. The Mylar sleeve was an ideal housing solution as its transparency made the print visible, thereby reducing handling and limiting potential damage. Also, we decided it was in the best interests of the collection to have all prints housed the same way and stored in the same location in the photography stacks.

\section{$\underline{\text { Digital Collection Content }}$}

With regard to digital content, web accessibility for this collection would naturally take place internally through the Ransom Center's CONTENTdm digital collection management system. This program has been used to place all of their digitized photography collections on their website, including the Julia Margaret Cameron Collection, the Stanley B. Burns, MD Tintypes, and the Elliott Erwitt Photography Collection. As the web accessibility is done internally and the detailed information would be taken directly from my cataloging

\footnotetext{
31 Lavédrine, Photographs of the Past, 286-290.
} 
database, my role was to provide the photographs for digitization and the data from my Filemaker cataloging database. From that point, Mary Alice Harper proofed the metadata and formatting of the database, while Jessica McDonald proofed the content. 


\section{Drocess}

\section{Researching the Collection}

Upon my arrival at the Ransom Center in January 2016, my logical first step was to go through the collection to assess the type, content, and overall condition of the prints. There are seventeen $20 x 24$ s, 152 $11 \mathrm{x} 14 \mathrm{~s}$, and three $8 \mathrm{x} 10$ sized prints in the collection. The first thing that struck me upon viewing the collection in its entirety was its heterogeneity, giving the overall impression of being a "grab bag" of sorts, containing prints of varying size, quality, condition, and subject matter. Alongside exhibition quality prints are ones that have been heavily marked for publication purposes. Additionally, there are a handful of duplicates as well as a few images that are blurry, scratched, or in which the subject matter is indeterminate.

The only documentation that I had to work with in the beginning of the project was a handwritten inventory by Roy Flukinger (Chief Research Curator of Photography) that had been completed shortly after the collection's arrival, and a survey of the collection conducted by Stephen Jareckie in 1996 (see fig. 1), then the Curator Emeritus of Photography at the Worcester Art Museum and the Photography Advisor at the Fitchburg Art Museum. Stephen Jareckie's survey, completed for the purposes of borrowing prints for an upcoming exhibition, detailed basic information as to size, subject (if known), a brief description for each print, and names and models of aircraft and ships, which was very effective in laying a foundation for my own research. I contacted Jareckie via email in February 2016 to ask for his permission to use the information in his survey for my research as well as to see if he had any further supplementary details to add about the collection. He very kindly gave me permission to use his survey and was enthusiastic about the project. He also sent me the brochure from the exhibition he did at the Fitchburg Art Museum called The Two-Ocean War, which featured forty-seven prints from the Ransom Center's collection.

As I examined the prints individually, taking preliminary notes on their condition and quality, I noticed that there were no captions or photographers' names written on the versos of the prints. I quickly learned that all 
published photographs taken by men in the unit were credited to the U.S. Navy instead of to the photographer, as was the protocol of the time. ${ }^{32}$ The only information on the verso of each print was an identification number, which consisted of one of four different letter prefixes followed by a number. Each prefix in the identification number denotes one of the following image classifications:

- $\underline{\text { BuAer }}$ - Bureau of Aeronautics photograph

- $\underline{\mathrm{MC}}$ - Marine Corps photograph

- $\underline{\mathrm{CG}}$ - Coast Guard photograph

- $\quad \underline{T R}$ - a Library of Congress subject classification denoting Technology/Photography

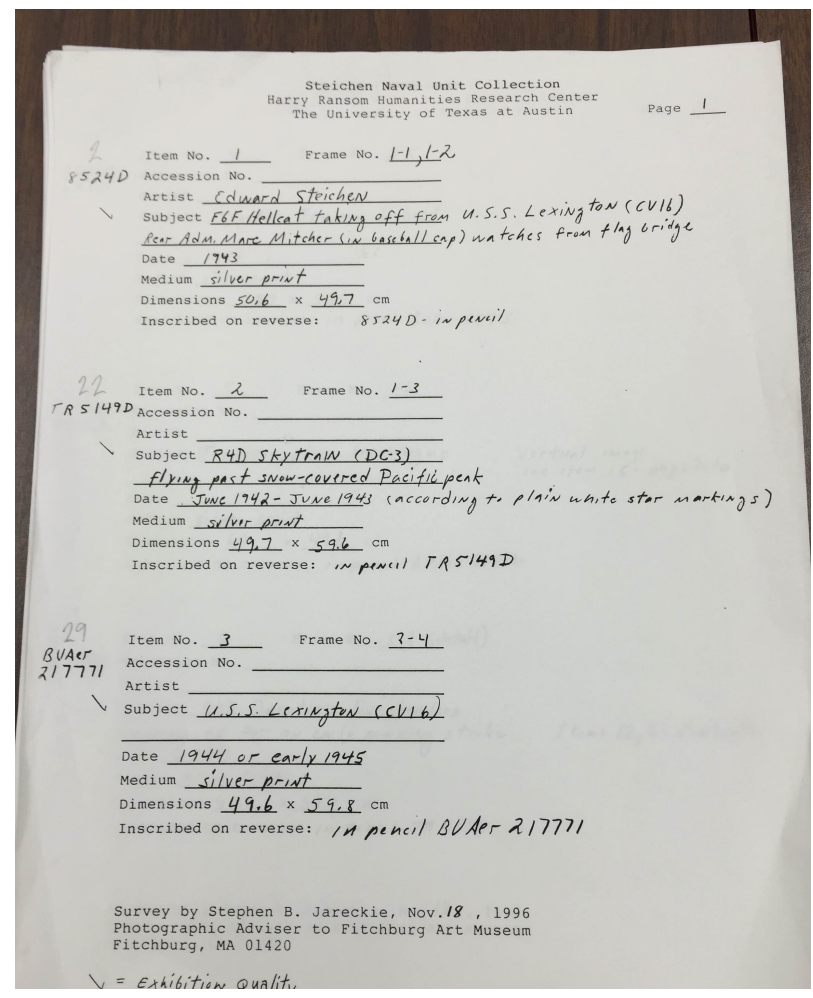

Fig. 1. Front page of Stephen Jareckie's collection survey.

My research trip to the National Archives and Records Administration in March 2016 did not prove as fruitful as I had anticipated. I looked at roughly four thousand negatives in the nine hours I spent

\footnotetext{
32 Faram, Faces of War, 91.
} 
there, and was dismayed to find that very few of the negatives listed the photographer who took them. I was able to identify the photographers of sixty-nine of the 172 images and the best-represented photographer by far is Steichen, with twenty-four images. There are several more that I strongly suspect are Steichen's as well, but I was unable to confirm that from my sources. The images that I was able to attribute to the photographer I did by way of the following: 1. I searched the National Archives and U.S. Naval Academy online collections to see if any of the Ransom Center's images were present and if so, see if the photographer was listed; 2. I looked through books (e.g. The Blue Ghost, Carrier War, U.S. Navy War Photographs, Power in the Pacific) and magazines (e.g. Life, Look, U.S. Camera) that reproduced images from the unit to see if any of the Ransom Center's collection images were represented; 3. Using all these sources, I was able to establish, for the most part, where and when the photographers were assigned throughout the war and if I knew where an image had been taken, I was usually able to pinpoint the photographer. However, there are many images for which there is little to no contextual information about subject or location, so identifying the photographer was not possible.

\section{Cataloging Database}

I consulted with Mary Alice Harper, the Head of Visual Materials Cataloging, as to what fields she needed to see in the database to maximize its usefulness going forward. Using the specifications given to me, and adhering to the Cataloging Cultural Objects (CCO) standards, I created a Filemaker Pro cataloging database with the following categories (see fig. 2):

- Accession number: The head cataloger gave me the number range at a later date, which is 974:0255:0001 - 974:0255:0172.

- Object ID: This was the identification number that had been previously written on the print verso. 
- Title: Due to the fact that no official titles had been given to the unit's images, I gave them all descriptive titles based on information gleaned from captions or the subject of the image, placed inside brackets.

- Title Source: Specifies where I got the title information from; if received from captions, the source is listed. If the title derived from the image subject, I entered 'descriptive title' in the field.

- Date: As there were none listed on the prints, I was able to find some dates from captions, some from determining which battles they were taken of, and for the ones I was unable to definitively identify, I listed an approximate date range based upon context clues, model and make of aircraft.

- Work type: Still image, per the Ransom Center's standards.

- Format: Black-and-white photograph, per the Getty's Art \& Architecture Thesaurus controlled vocabulary.

- $\quad$ Dimensions - Obj.: The size of the object, in centimeters.

- Dimensions - Image: The size of the image, in centimeters.

- $\quad$ CCO dimensions: The sizes of the object and image, respectively, in centimeters.

- Inscriptions: The information that has been imprinted on the recto or verso, including method (inscribed, typed, stamped, or signed), implement (pencil, pen, stamp, etc.), and location on the print (upper left, lower left, center, upper right, lower right).

- Publication info: The magazines and books in which the photographs were published. One of the ways I want to distinguish this online database of the unit's images from those of the National Archives and the U.S. Naval Academy is to include information that cannot be found elsewhere that might be useful to potential researchers; thus I compiled a comprehensive list (to the best of my ability) of the magazines and books in which each image was published.

- Subject: Library of Congress authorized subject headings are listed for each image based on the image content. Headings range from general (e.g. War photography-20 $0^{\text {th }}$ century; World War, 1939-1945) to specific (e.g. Monterey (Aircraft carrier); Hellcat (Fighter planes)) in order to broaden the search capabilities of the database. There were a handful of images in which the subject was either unknown or ambiguous due to blurriness in the image - for these, I simply entered "Subject unknown" in the field.

- Description: I obtained the information used in the description field from captions in magazines and books if the images had been published; for the unpublished images, I utilized descriptors from Jareckie's original survey and searched the National Archives and U.S Naval Academy's databases for the same images or similar ones that may have been part of the same series. 
- Notes: In this field, I listed two pieces of information when applicable:

1. Images that had been part of the Power in the Pacific exhibition

2. Duplicate images

The database contained a combination of descriptive (information about the work) and administrative (information about image capture and rights restrictions) metadata of specific use to her in formatting the database for CONTENTdm compatibility. ${ }^{33}$
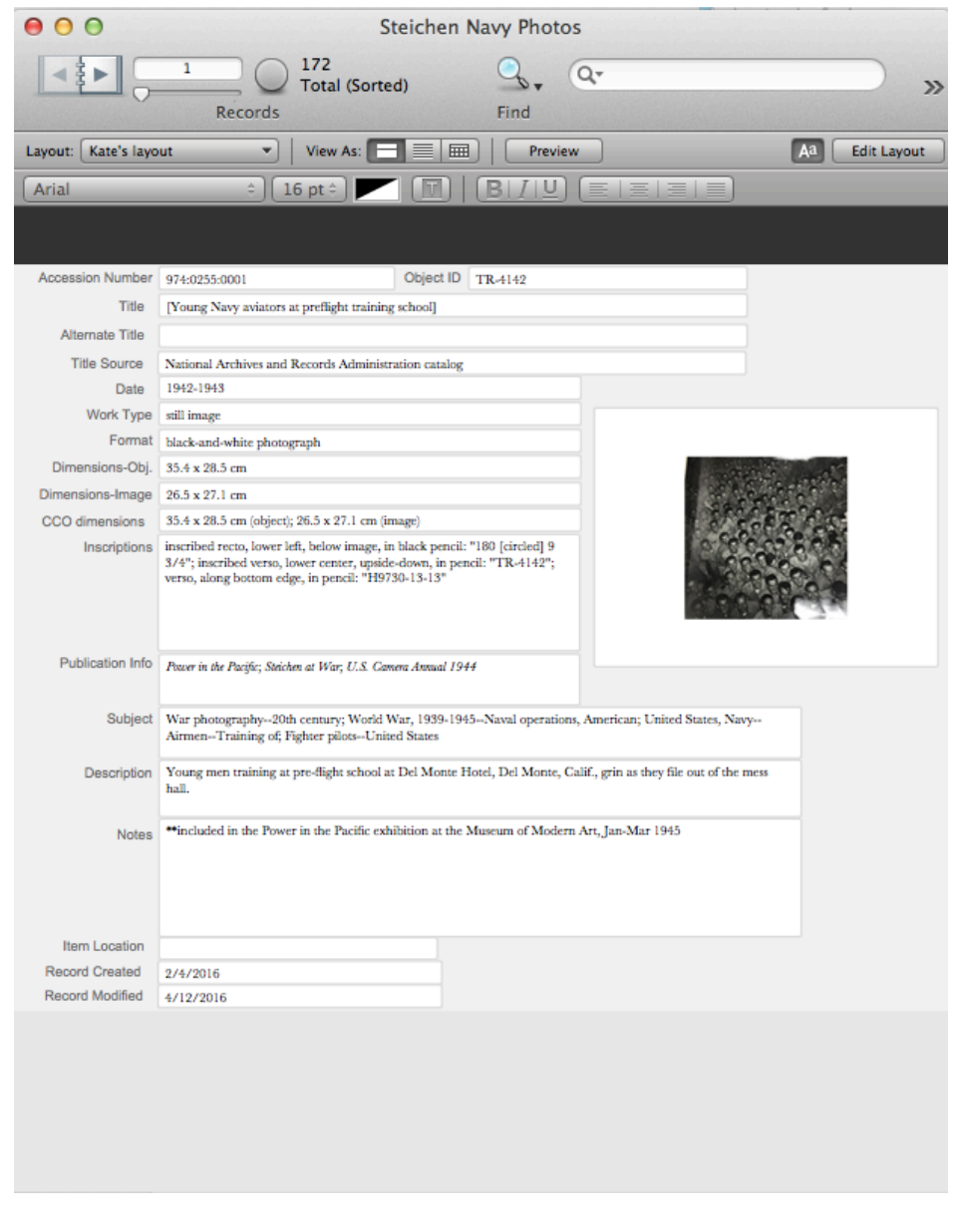

Fig. 2. Screenshot from the Filemaker Pro collection database.

It soon became apparent to me when originally assessing the collection that there was no discernible meaning behind the order of the prints in their boxes. The ordering yielded no insight into content,

\footnotetext{
${ }^{33}$ Ritzenthaler and Connor, Photographs, 399.
} 
photographer, or date taken; thus the option of keeping the collection in its original order was moot. ${ }^{34}$ As a result, I organized the collection into an intellectual rather than physical arrangement, one based on subject and chronology. ${ }^{35}$ Due to the dearth of identifying information on the prints, organizing it became a fairly involved process. My intent was to arrange the images in as cohesive a manner as possible in an attempt to simulate a contextual narrative format, one that leads a potential viewer through the unit's documentation of the war from beginning to end. With this in mind, I sorted my Filemaker entries by date photographed (or estimated date), and then grouped and re-grouped images from the same battles, ship, or theme; I did this several times until I was happy with the order and flow of the prints. The accession number range for the collection is 974:0255:0001-974:0255:0172, with the photographs arranged in ascending date order, beginning in 1942-43 and ending in 1945. Per department protocol, I wrote the accession number in pencil in the lower right corner, along the bottom edge of each print verso.

\section{Digitization}

As procedure at the Ransom Center requires that objects be accessioned and cataloged before they are digitized, I proceeded with cataloging the objects in the Filemaker database with the intention of rearranging the entries later on. Also, before digitization could commence on my project, I needed to fill out the digital projects proposal form for the Digitization Lab so that they could arrange their workflow accordingly. The form required the following information: working project title, project summary, justification, materials to be digitized, status of the materials, any relevant preservation aspects/goals/considerations, deadlines, and copyright/intellectual property rights information on the collection. Next, Linda Briscoe Myers, Assistant Curator of Photography, showed me how to access the

\footnotetext{
34 Ritzenthaler and Connor, Photographs, 146-147.

35 Ibid.
} 
Ransom Center's internal network to create digitization requests for each individual print and submit them electronically (see fig. 3). The required information on each request included: collection name, accession number, creator, creation date, title, and format. I then printed out these requests and placed them on top of the respective prints and transported them on a cart to the Digitization Lab.

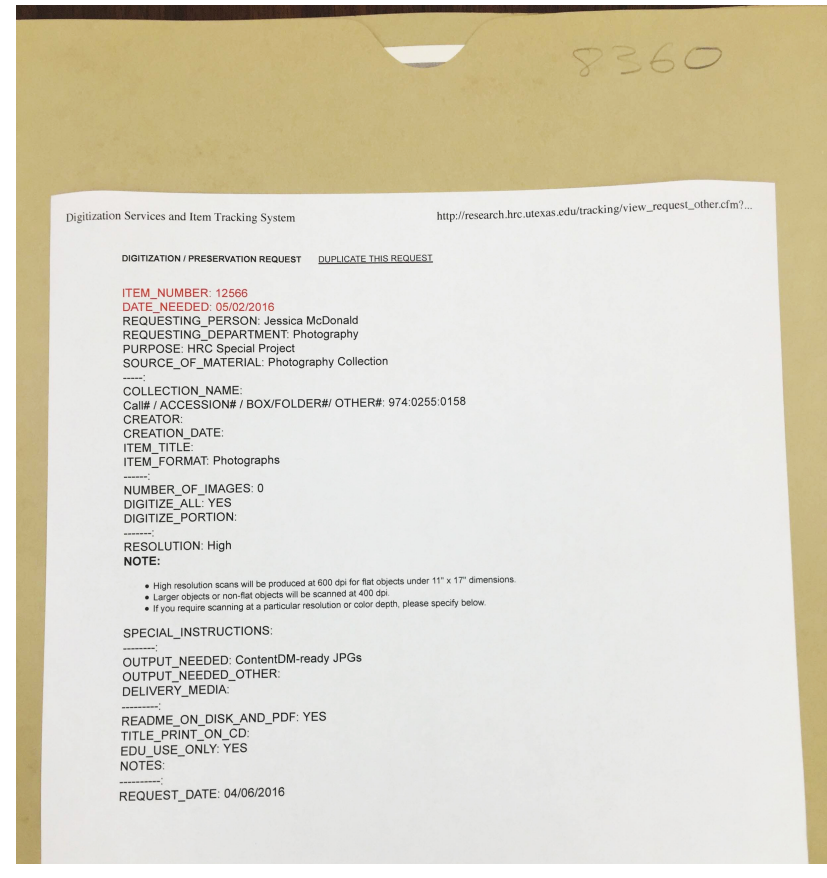

Fig. 3. Ransom Center digitization request.

\section{Housing}

Housing the Steichen unit prints required balancing the preservation needs and reading room usage of the prints with the storage space available for the Ransom Center's photography collection. Due to storage concerns, the photography collection is all housed in one of three ways: in a Mylar sleeve, on mat board inside Mylar sleeve, or matted, though only a very small percentage of the photography collection is matted. When I began my project, the Steichen unit collection had been housed in three different ways: the three 8x10 prints were stored flat on mat board with a Mylar covering; the 152 11x14 prints were stored in acid-free, buffered paper sleeves, and lying flat in two archival, drop-front boxes; fourteen of 
the 20x24s were stored in large, yellowing glassine sleeves while three of the 20x 24 s were fully matted to a 24x36 size and stored separate from the rest of the collection in the oversize print drawers within the photography stacks. Jessica McDonald and I had jointly decided that it would be in the best interests of the collection to have all of the prints housed in the same manner and stored together. Moreover, we determined that in order to reduce potential handling of the original prints, the preferred housing would be transparent to ensure that the prints are both fully visible and protected. To that end, and after consulting with the Preservation and Conservation Department, we settled on the prints flat on 40 point lignin-free board, and enclosed in 3 mil archival Mylar sleeves, edge sealed on three sides with the opening on the short side (see fig. 4). All three sizes of prints were then placed in drop front boxes labeled "Edward Steichen Naval Aviation Photographic Unit Collection" with accession number ranges to facilitate access for future research, and placed on a designated shelf in the photography stacks.

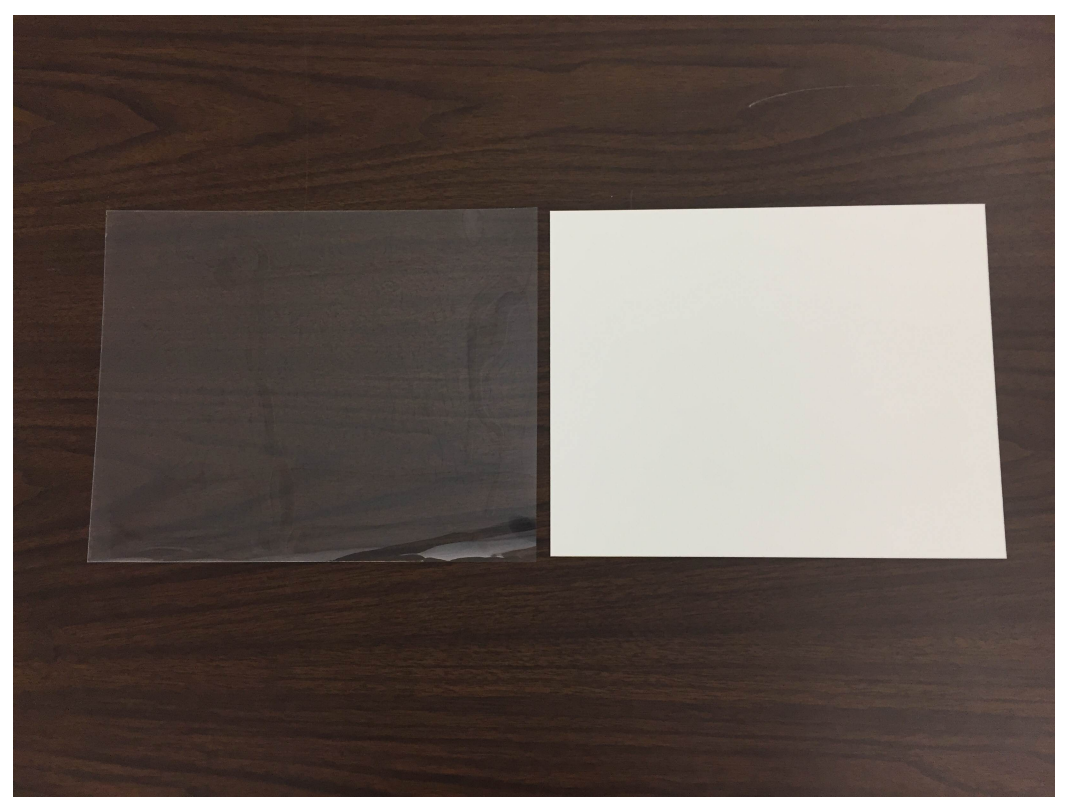

Fig. 4. The basic housing package: 40pt. Lignin-free board and Mylar sleeve 


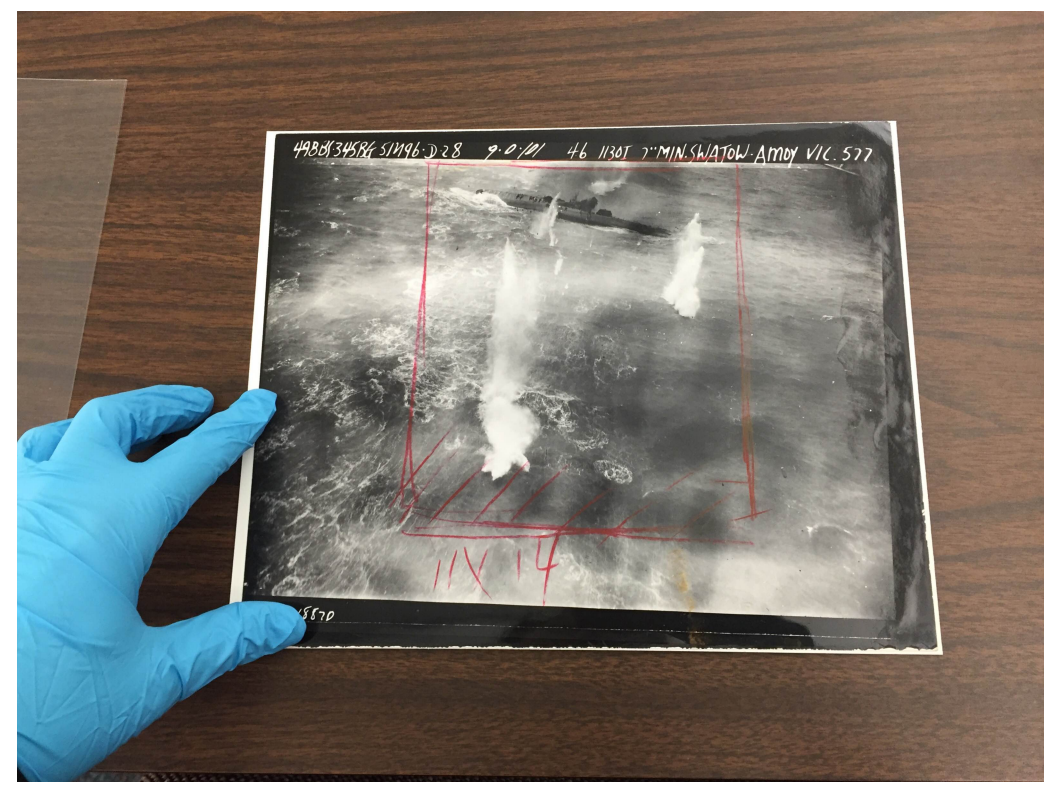

Fig. 5. The print is centered on the board first, then slid into the Mylar sleeve.

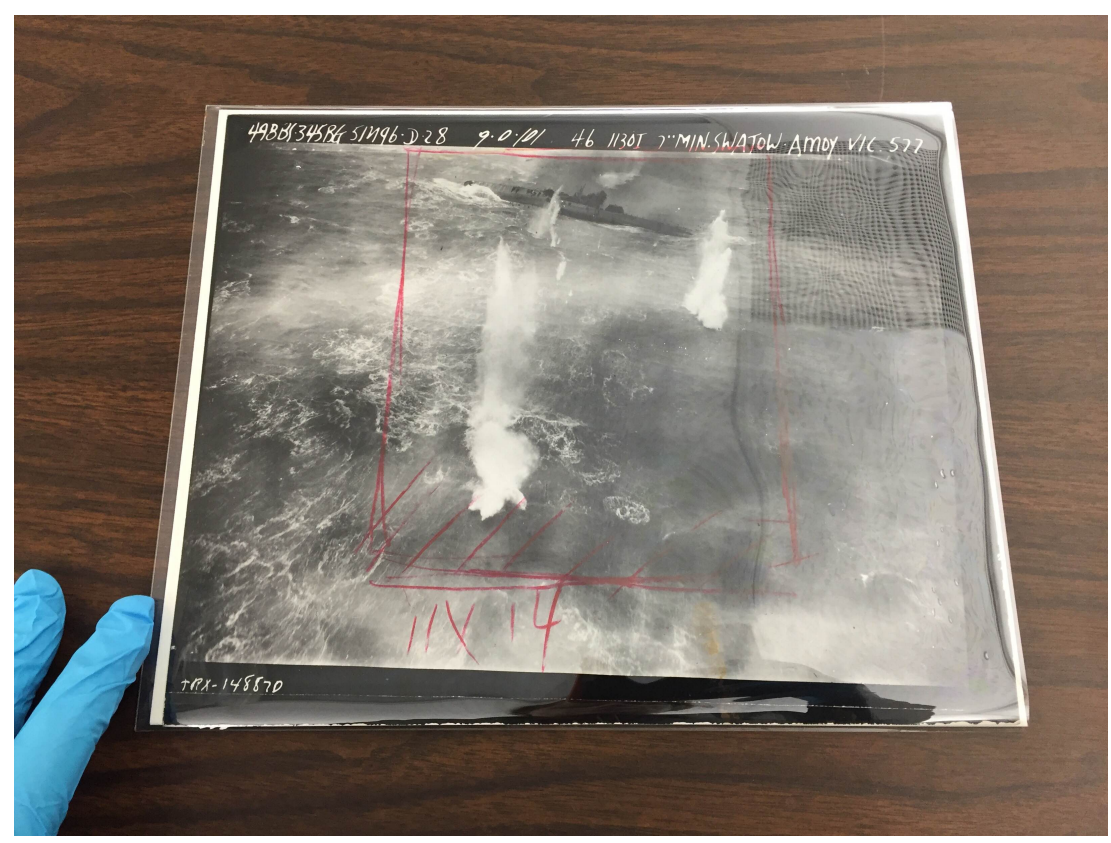

Fig. 6. A completed housing package for an $8 \times 10$ print. 


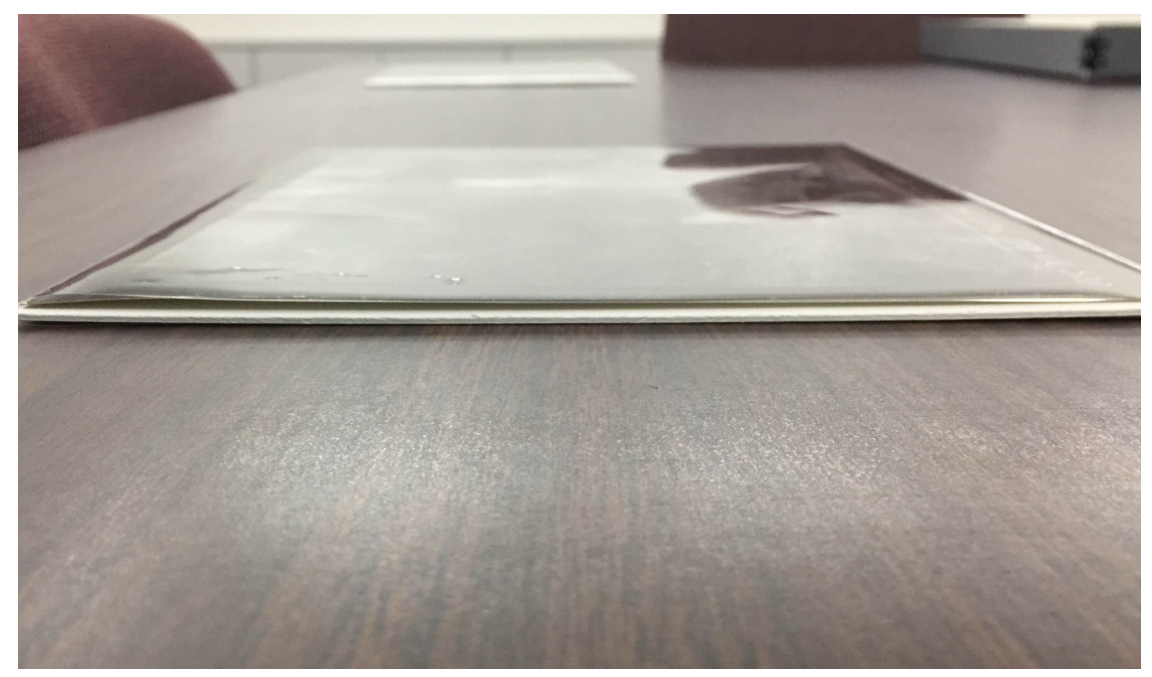

Fig. 7. A completed housing package for an $8 \times 10$ print. Side view.

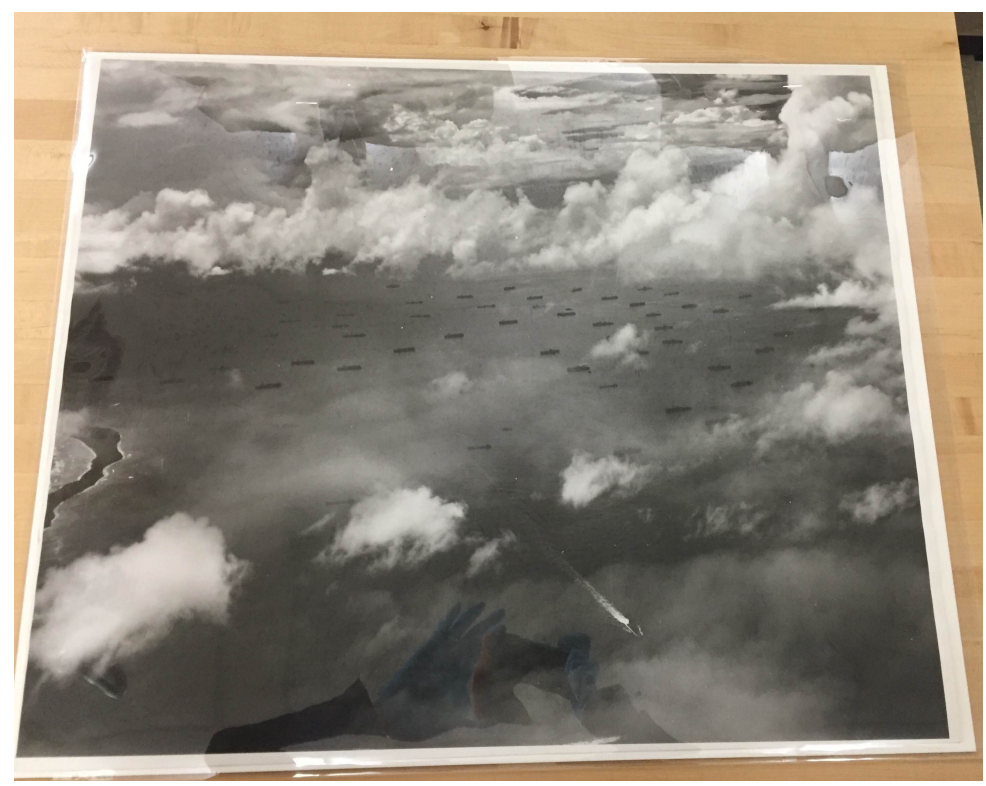

Fig. 8. A completed housing package for a 20x24 print. 
The final measurements (in inches) for the print, Mylar, board, and box sizes are the following:

$\begin{array}{cccc}\text { Print } & \underline{\text { Mylar sleeve }} & \text { 40 point lignin-free board } & \underline{\text { Box }} \\ 8 \times 10 & 87 / 16 \times 107 / 16 & 81 / 4 \times 101 / 4 & 9 \times 12 \\ 11 \times 14 & 117 / 16 \times 147 / 16 & 111 / 4 \times 141 / 4 & 16 \times 20 \\ 20 \times 24 & 207 / 16 \times 247 / 16 & 201 / 4 \times 241 / 4 & 24 \times 30\end{array}$

The Mylar sleeve/packages for all three sizes were custom-made in the Preservation and Conservation Department. Due to the fact that Alan van Dyke, Technical Staff Assistant in the Preservation Lab and the person in charge of supplies ordering, attempted without success to find a Mylar/lignin-free board package that was between $11 \times 14$ and 13x19, he proposed having the housing packages made in-house by an intern in the Preservation and Conservation Department. The actual print housing process itself was very straightforward and I was able to complete it in two days. The process consisted of placing the print onto the board and sliding the print and board together into the Mylar sleeve carefully so as not to scrape or bend the print in the process (see fig. 5). The result was a print enclosed in a firm, but not overly tight, package that would be safe for both display and public handling (see figs. 6-8). The only exception to the housing involved one print mounted on composite board that had been sent to the Education and Exhibitions Division so that they could construct a sink mat for it.

\section{Digital Collection Content}

The images would be digitized and made accessible online via CONTENTdm, the digital collection management system the Ransom Center uses for all of its digital collections. The CONTENTdm system imports the metadata from the cataloging database I created, integrates it with the digital image file, and uploads the content to the Ransom Center's website in a searchable format. As the unit's photographs 
have not yet been uploaded to the Ransom Center's site, I have included a screenshot of the Julia

Margaret Cameron digital collection from their site, which illustrates the same format and layout that will be used for the unit collection (see fig. 9). I have also included screenshots of the image zoom function (see fig. 10) and the description information on the detail page (see fig. 11), which will be populated by the fields in my database.

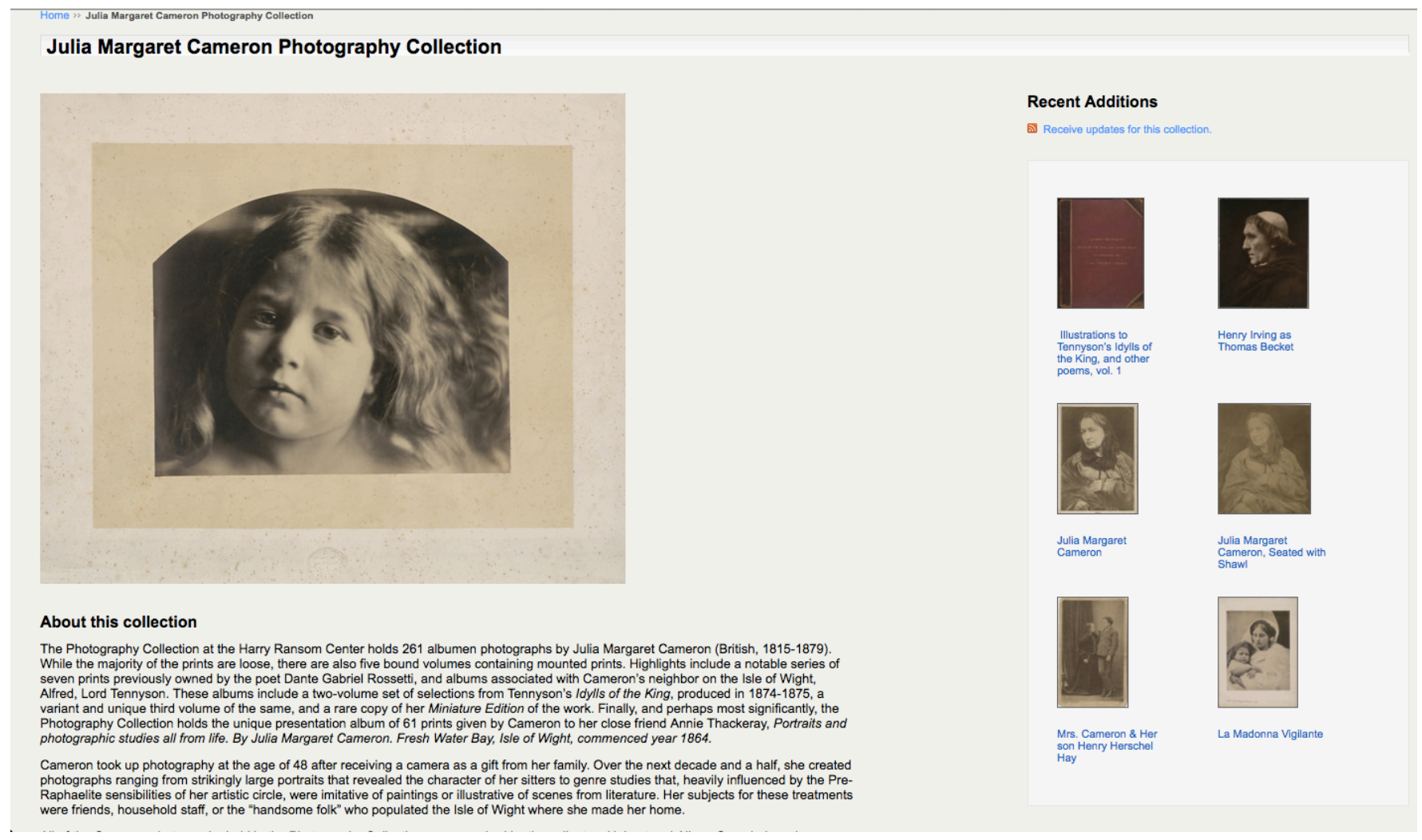

Fig. 9. The Julia Margaret Cameron Photography Collection page on the Ransom Center's Digital Collections webpage. This closely approximates how The Edward Steichen Naval Aviation Photographic Unit Collection will be presented. 


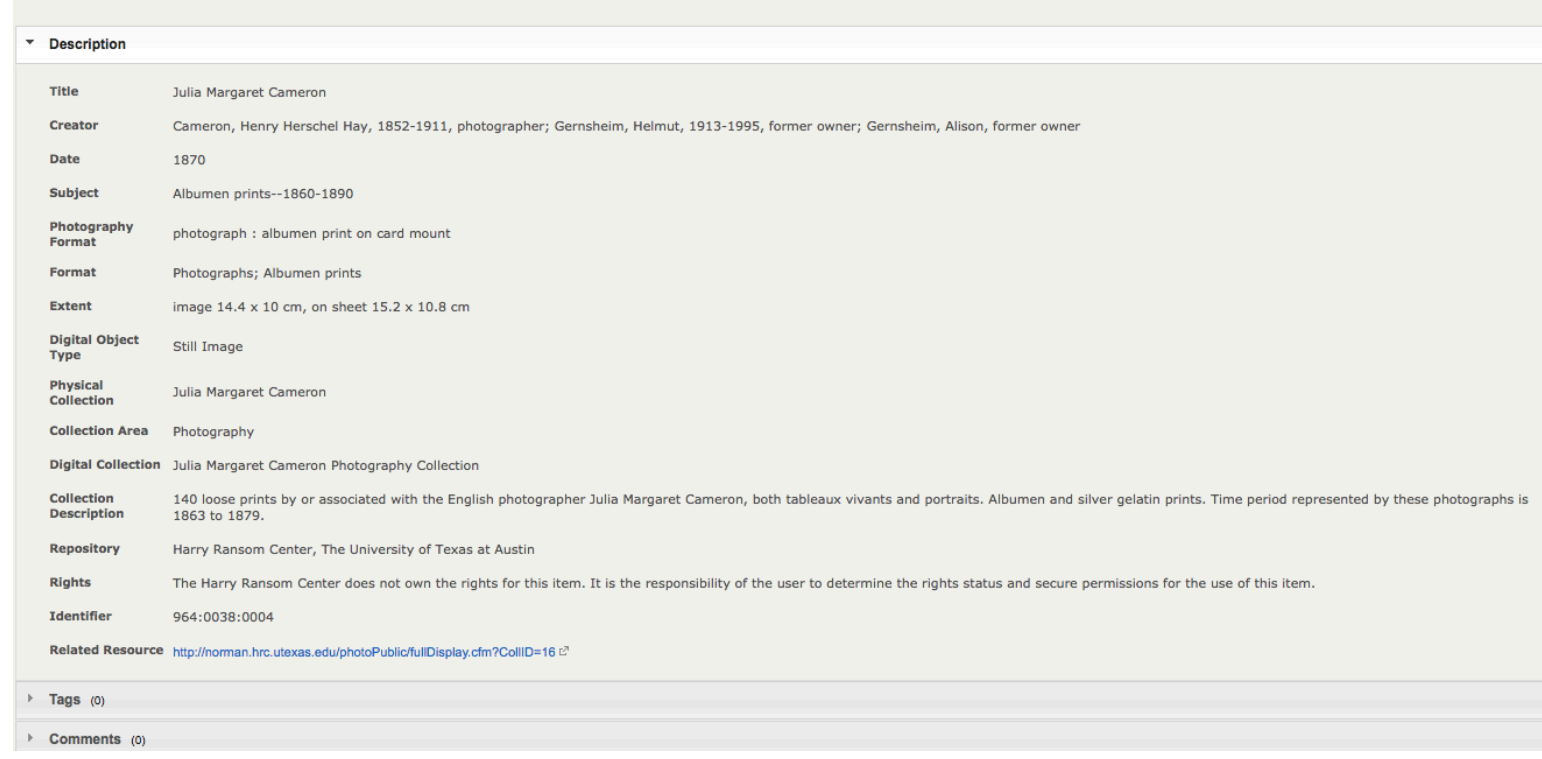

Fig. 10. Description information: The detail fields will be imported from my Filemaker Pro database and appear below the image.

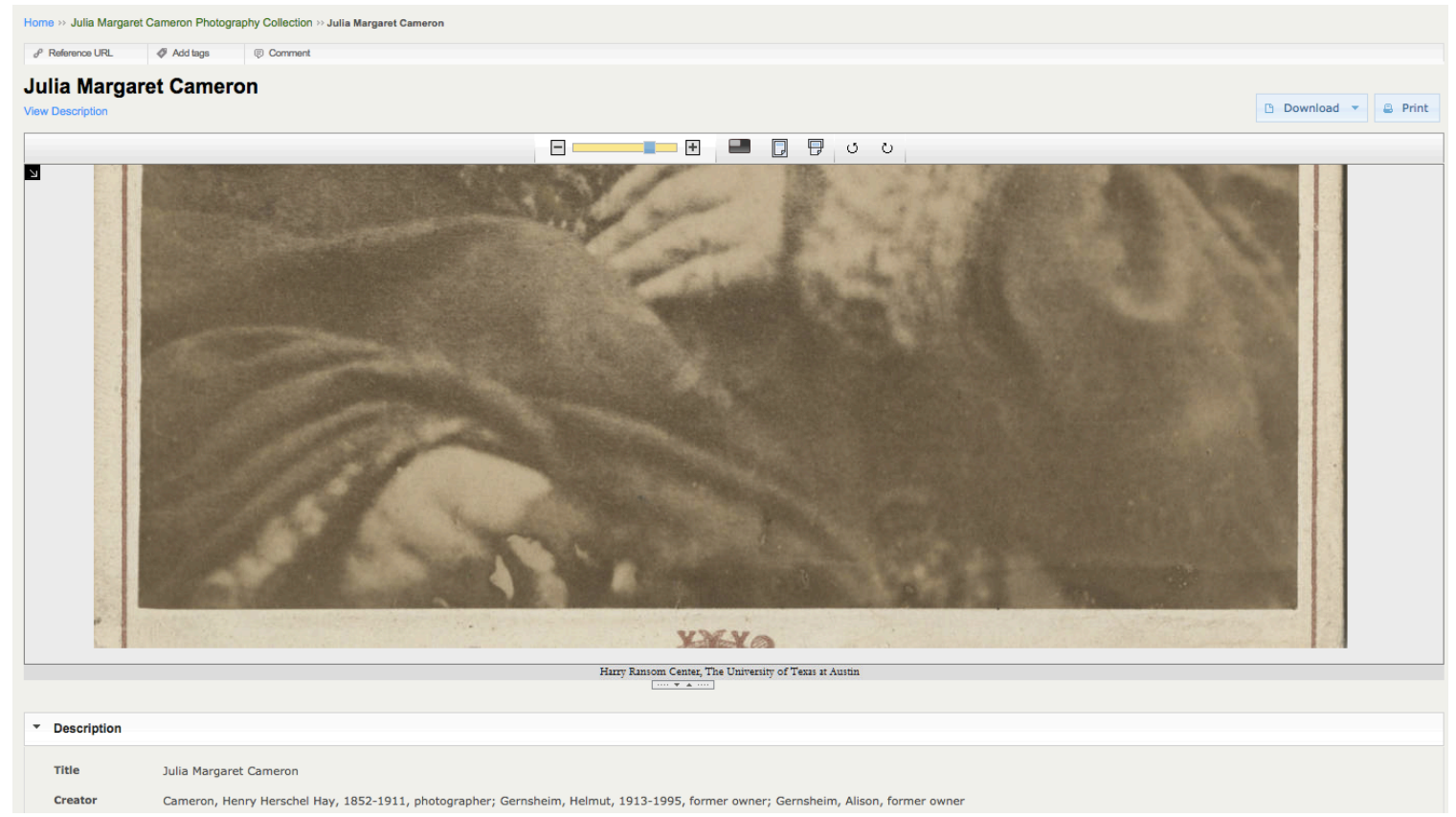

Fig. 11. Image detail: The ability to zoom in closely on a high resolution image will be useful for researchers in viewing inscriptions, aircraft, and weaponry. 


\section{口Conclusion}

This project provided the perfect opportunity for me to gain immensely valuable hands-on experience processing a photography collection while at the same time helping the Ransom Center's Photography Department to catalog more of their collection. Furthermore, from this process I learned a great deal about working with the limitations inherent in public institutions. As funding and staff are often in short supply in public institutions, departments must prioritize their resources with regard to working with their collections. Consequently, many collections get overlooked in these institutions because the resources just are not there to research and catalog them. The Ransom Center's Photography Department contends with these same limitations, which goes a long way towards explaining why the Steichen naval photographs remained un-accessioned for forty years.

The work of the Naval Aviation Photographic Unit remains historically relevant for its substantial role in laying the foundation for a style of evocative and powerful conflict imagery that has continued to be practised by the field's preeminent war photojournalists. Photographers such as Werner Bischof, David Douglas Duncan, Larry Burrows, Donald McCullin, Philip Jones Griffiths, Dickey Chappelle, Henri Huet, James Nachtwey, Tim Hetherington, Nina Berman, Chris Hondros, Simon Norfolk, Ashley Gilbertson, and Lynsey Addario, just to name a few, have created compelling imagery that continues a tradition that grows from the imagery of World War II. The impact that the unit had and continues to have on images from conflict zones was evinced by the Museum of Fine Arts, Houston's massive 2012 war photography exhibition $W$ ar/Photography, which featured ten of the unit's photographs and included a paragraph on the unit in the exhibition catalog. ${ }^{36}$

\footnotetext{
36 Anne Tucker, Will Michels, and Natalie Zelt, War/photography: Images of Armed Conflict and Its Aftermath (Houston: Museum of Fine Arts, Houston, 2012), 142.
} 
The photographs taken by the unit are distinguishable from other World War II images for their technical skill, dynamic composition, and refined perspective. My hope is that making the images accessible on the Ransom Center's site will spark interest about the collection and inspire further research into the photographs. The Ransom Center's collection, though small in size, is nonetheless significant in scope. Every one of the photographers in the unit is represented in the collection. Nearly forty percent of the images were published in books of the time such as The Blue Ghost, U.S. Navy War Photographs, and Carrier War, as well as in Life, Look, and U.S. Camera magazines; in fact, many of the prints bear crop marks, measurements, and other evidence of publication. Fifteen percent of the images were part of Steichen's Power in the Pacific exhibition (though the Ransom Center prints are not the actual exhibition prints), which ran at MoMA from January through March of 1945, and were subsequently published in the accompanying catalog. Furthermore, the unit's work fills an important niche by adding a naval component to the World War II photographs in the Ransom Center's collections, chiefly within the David Douglas Duncan and Magnum archives.

The unit is still a relatively obscure entity, despite having so many photographs published during the war. I think this is at least partially due to the fact that individual photographers in the unit were not credited for their photographs in publications, as this was forbidden for photographers in the U.S. Navy. While contemporaneous civilian war photographers like Robert Capa and W. Eugene Smith (whose images were published frequently in Life magazine) entered the pantheon of great war photographers, the unit's photographers saw their work attributed solely to the U.S. Navy, failing to receive the same level of attention and renown. Accordingly, I think it is important to make collections like the Ransom Center's accessible, both to foster the public's enduring interest in World War II photography and encourage further research into the photographs and the men who took them. 
The size of the Ransom Center's collection presents a unique opportunity to prominently display the entirety of it online, and in so doing, present the work to a whole new audience. Likewise, the original photographic prints have been fully accessioned, cataloged, and re-housed and are now publicly accessible. There is still so much to be learned about this collection, and I hope that my research has laid a solid foundation upon which others can build. 


\section{Bibliography}

Bradford, Dave. "Naval Aviation News." Naval Aviation News. February 24, 2014. Accessed April 14, 2016. http:// navalaviationnews.navylive.dodlive.mil/.

Brothers, Caroline. W ar and Photography: A Cultural History. New York: Routledge, 1997.

Bülow, Anna E., and Jess Ahmon. Preparing Collections for Digitization. London: Facet Publishing, 2011.

Faram, Mark. Faces of War: The Untold Story of Edward Steichen's WWII Photographers. New York: Berkley Caliber, 2009.

Jorgensen, Victor H., Papers. MS 21. Special Collections and Archives, University Library, University of California, Santa Cruz.

Lavédrine, Bertrand. Photographs of the Past: Process and Preservation. Los Angeles: Getty Conservation Institute, 2009.

Lisle, Debbie. “The 'Potential Mobilities' of Photography.” M/C Journal 12, no. 1 (March 2009). Accessed February 12, 2016. http://journal.media-culture.org.au/index.php/mcjournal/ article/view/125.

Maloney, Thomas J., ed., and Edward Steichen. U.S. Camera Annual 1943. New York: Duell, Sloan and Pearce, 1942. . U.S. Camera Annual 1946-Victory. New York: U.S. Camera Publishing Corporation, 1945.

- U.S. Navy War Photographs: Pearl Harbor to Tokyo Bay. New York: Crown Publishers, Inc., 1980.

Phillips, Christopher. Steichen at War. New York: Harry N. Abrams Co., 1981.

Ribalta, Jorge. Public Photographic Spaces: Exhibitions of Propaganda, from Pressa to The Family of Man, 1928-55. Barcelona: Museu D’Art Contemporani De Barcelona, 2008.

Ritzenthaler, Mary Lynn, and Diane Connor. Photographs: Archival Care and Management. Chicago: Society of American Archivists, 2006.

Saretzky, Gary. "U.S. Camera: A Thomas J. Maloney Chronology.” Photo Review 26, no. 4 (Winter 2004).

Siegel, Nan. "Edward Steichen Goes to War." Aviation History 18, no. 3 (January 2008): 40-47. http:/ / ezproxy.lib.ryerson.ca/login?url=http://search.proquest.com/docview/ 219838289 ?accountid=13631. 
Steichen, Edward. Power in the Pacific: A Pictorial Record of Navy Combat Operations on Land, Sea and in the Sky. New York: U.S. Camera Publishing Company, 1945.

The Blue Ghost. A Photographic Log and Personal Narrative of the Aircraft Carrier USS Lexington in Combat Operations. New York: Harcourt Brace, 1947.

—. A Life in Photography. New York: Doubleday, 1963.

Tucker, Anne, Will Michels, and Natalie Zelt. War/photography: Images of Armed Conflict and Its Aftermath. Museum of Fine Arts, Houston, 2012.

Warren, Mame. "Focal Point of the Fleet: U.S. Navy Photographic Activities in World War II." The Journal of Military History 69, no. 4 (2005): 1045-1079. Accessed September 20, 2015. doi:10.1353/jmh.2005.0268.

"Wayne Miller Biography." Magnum Photos. May 2013. Accessed March 1, 2016. https://pro.magnumphotos.com/C.aspx?VP3=CMS3\&VF=MAGO31_9_VForm\&ERID=24KL534 NBZ. 


\section{Appendix A: Selected Photographs from the Collection}

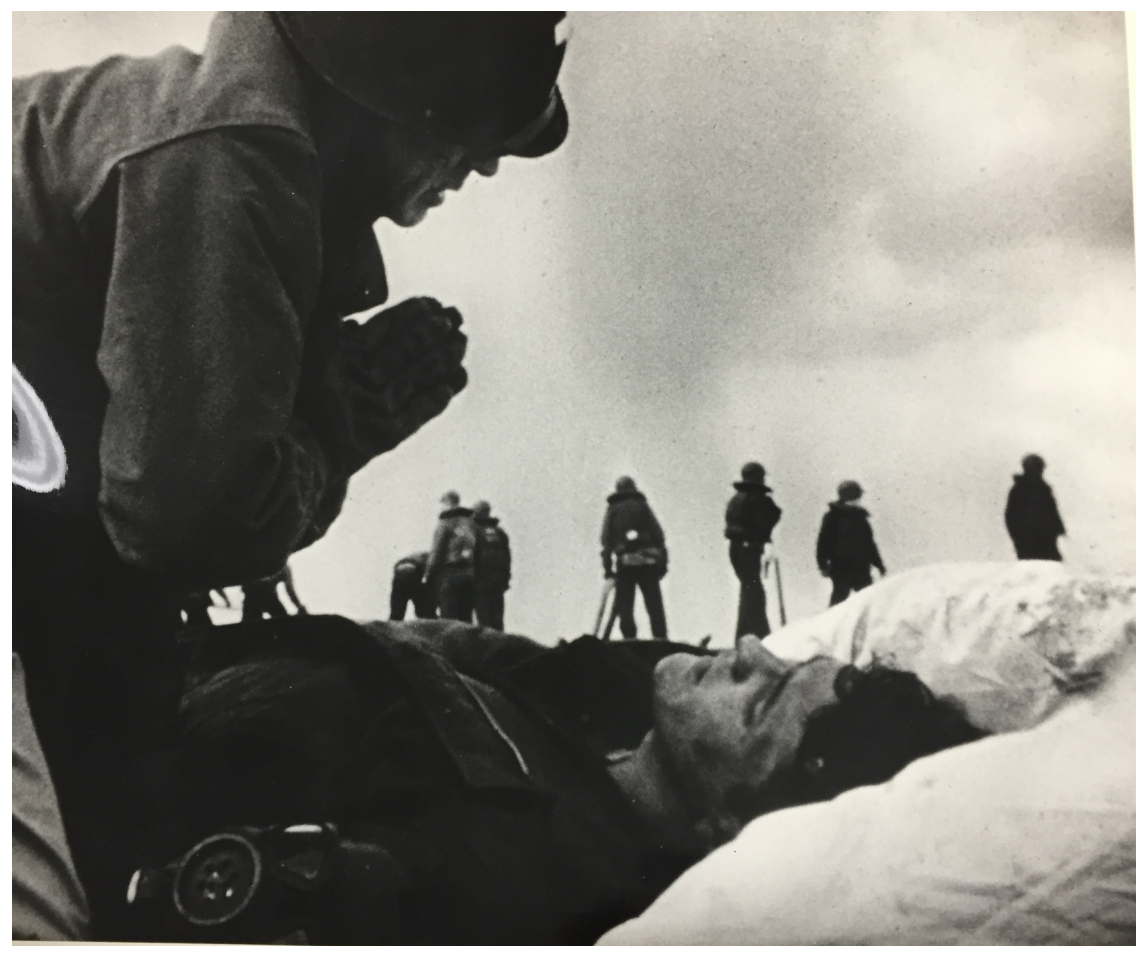

Fig. 12. Photographer unknown, Last Rites Aboard the USS Franklin, 1945, Gelatin silver print, $27.2 \times 34.2 \mathrm{~cm}$, The Edward Steichen Naval Aviation Photographic Unit Collection, 974:0255:0168.

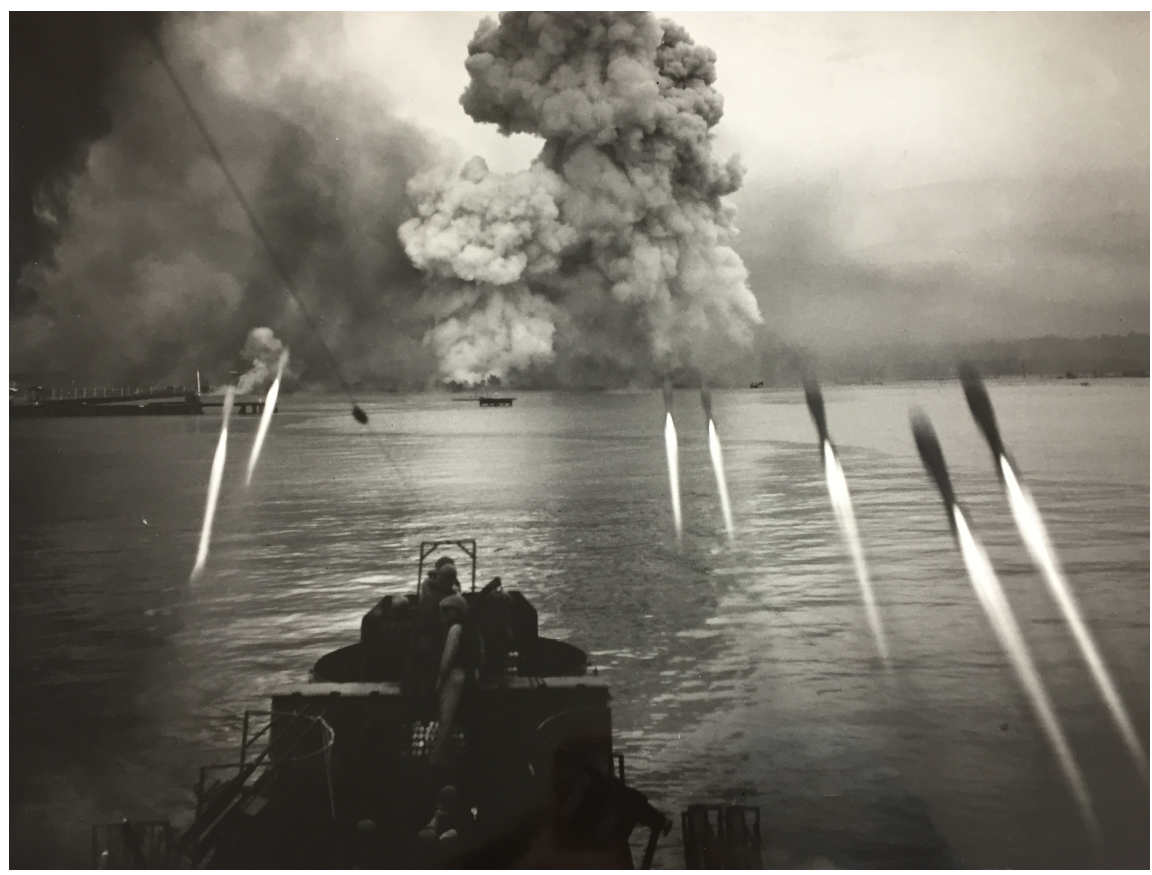

Fig. 13. Photographer unknown, [LCI rocket attack], 1944, Gelatin silver print, 27.1 x $34.4 \mathrm{~cm}$, The Edward Steichen Naval Aviation Photographic Unit Collection, 974:0255:0134. 


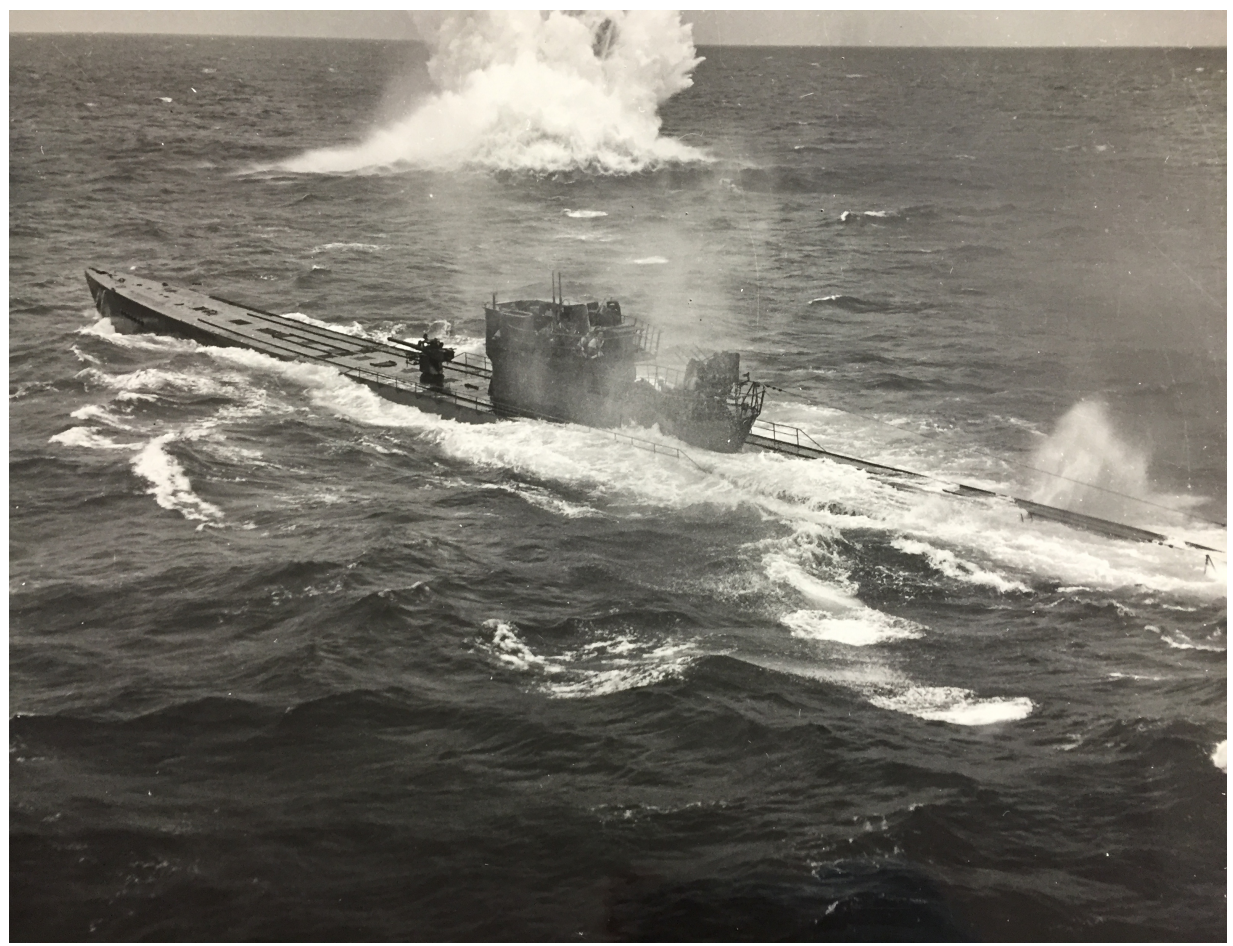

Fig. 14. Photographer unknown, U-Boat Sailors Cringe from Depth Bomb, 1943, Gelatin silver print, $27.3 \times 34.3 \mathrm{~cm}$, The Edward Steichen Naval Aviation Photographic Unit Collection, 974:0255:0069.

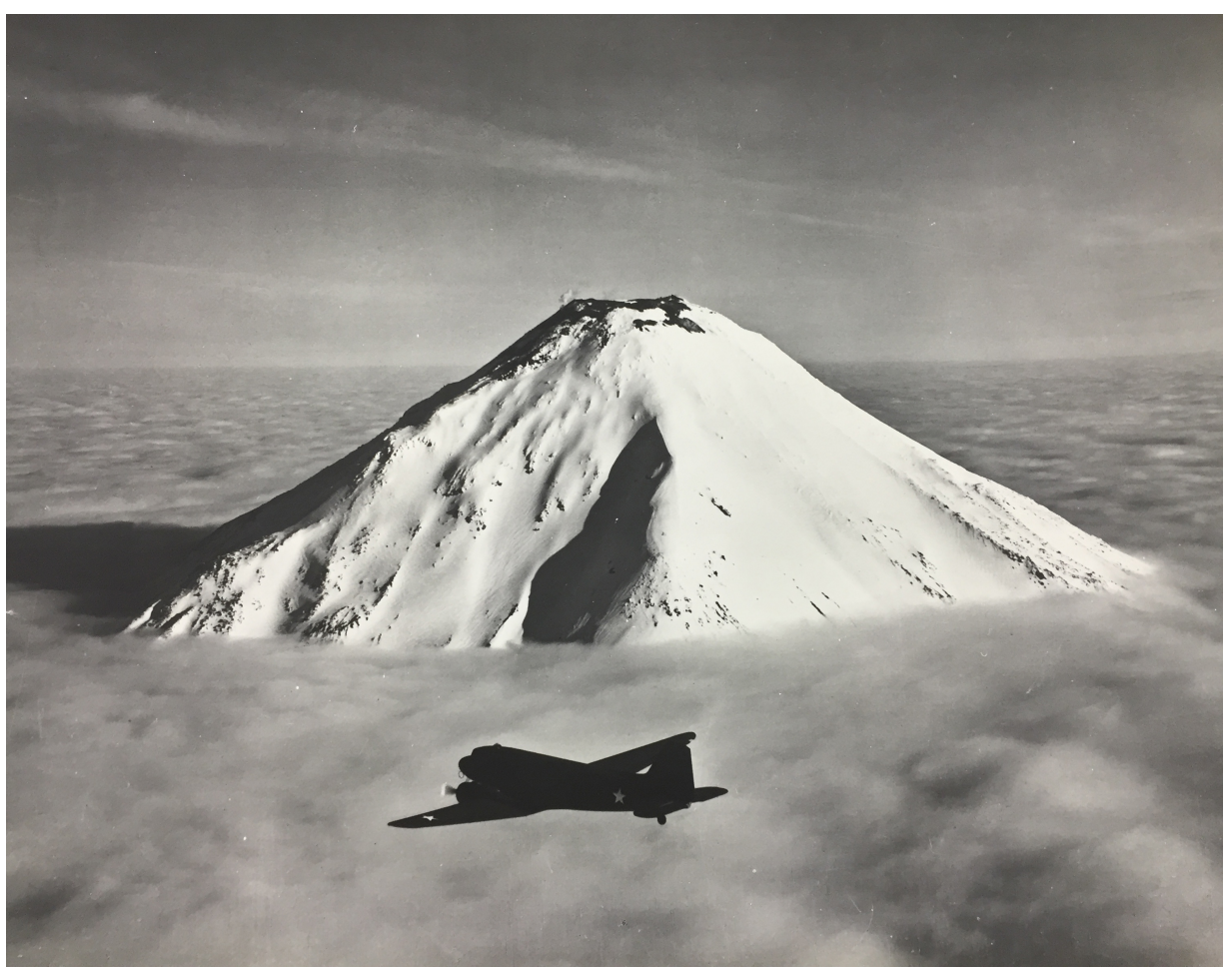

Fig. 15. Horace Bristol, Gareloi Volcano, 1943, Gelatin silver print, 49.8 x $59.5 \mathrm{~cm}$, The Edward Steichen Naval Aviation Photographic Unit Collection, 974:0255:0015. 


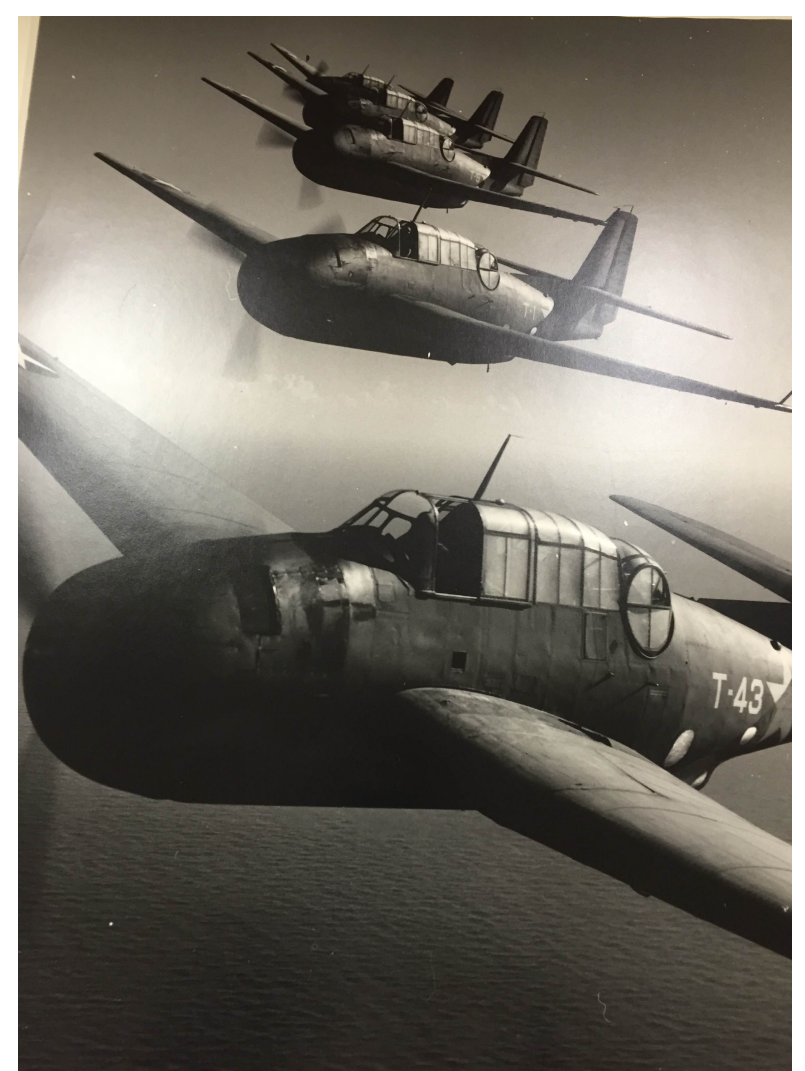

Fig. 16. Horace Bristol, Angry Avengers, 1943, Gelatin silver print, 59.4 x 49.8 cm, The Edward Steichen Naval Aviation Photographic Unit Collection, 974:0255:0016.

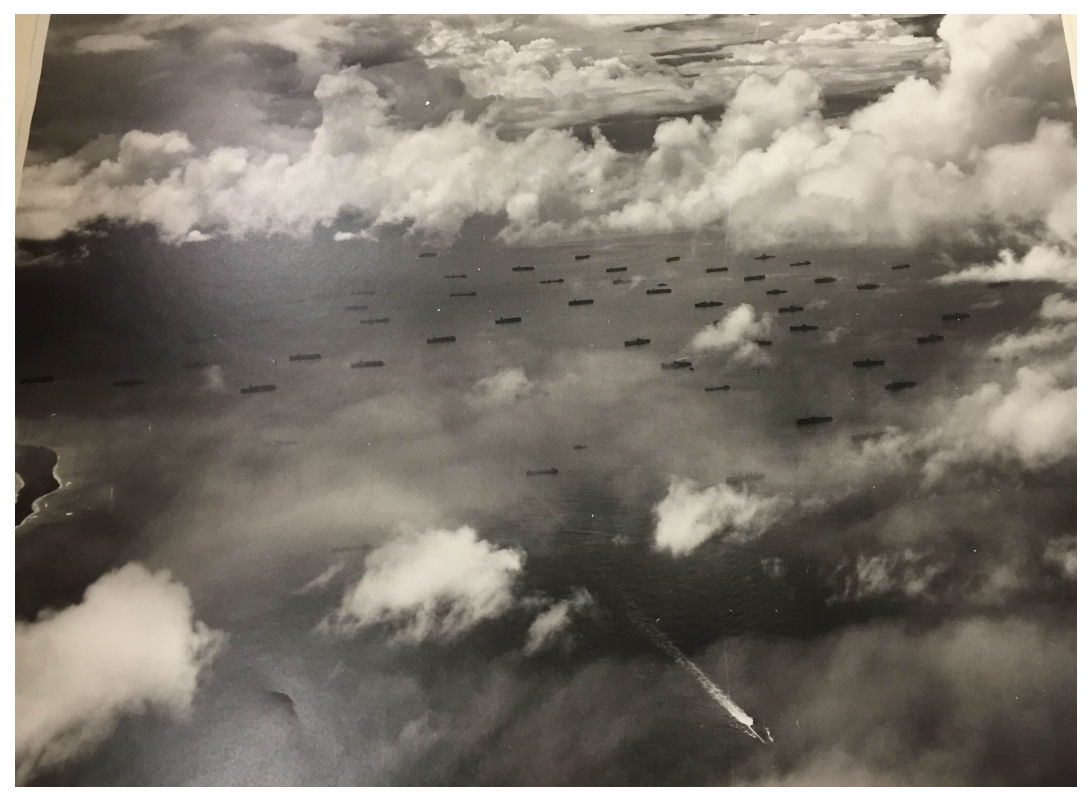

Fig. 17. Edward Steichen, [Battleships From Above], 1943-1945, Gelatin silver print, 49.9 x $59.9 \mathrm{~cm}$, The Edward Steichen Naval Aviation Photographic Unit Collection, 974:0255:0118. 

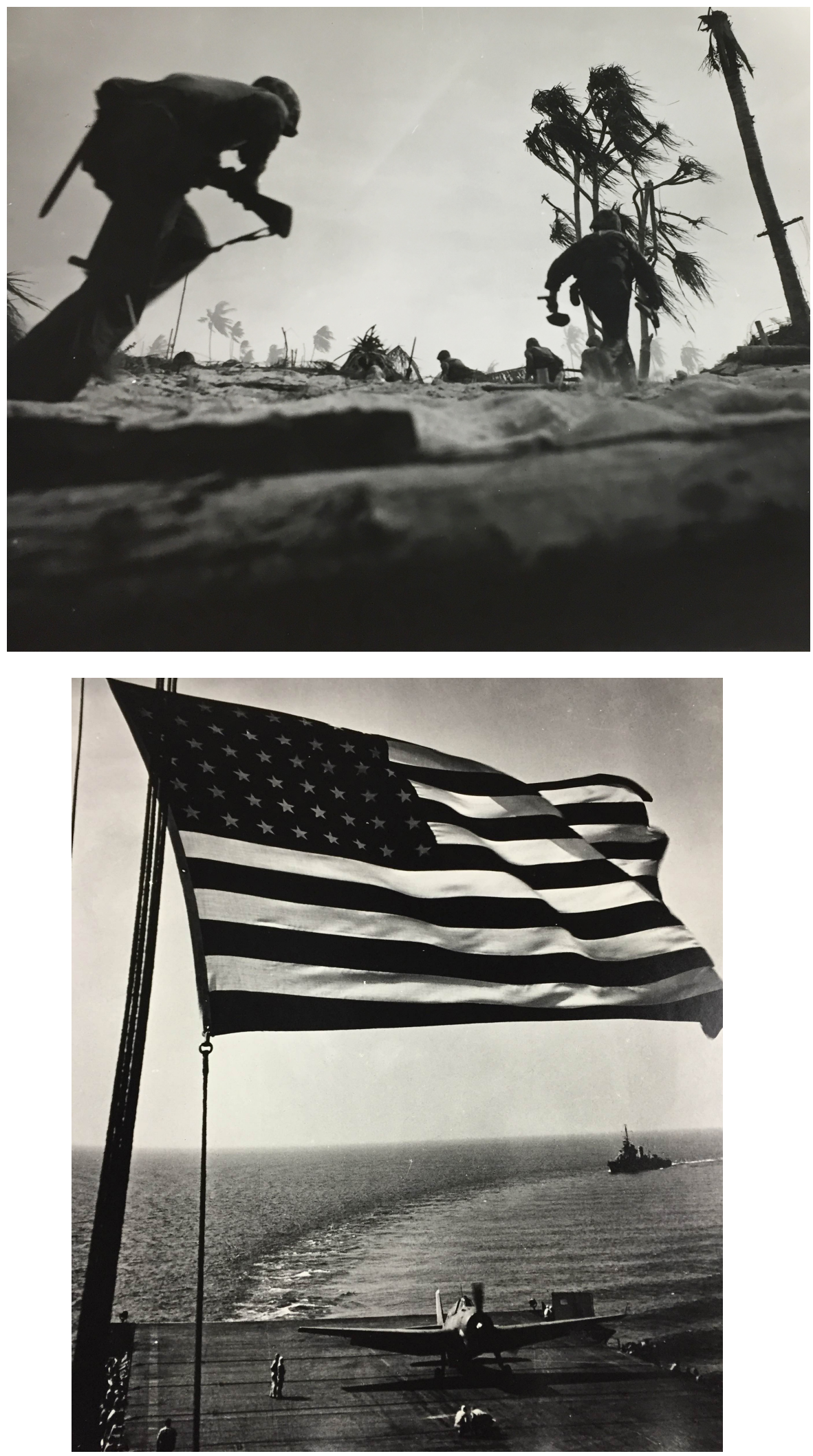

Fig. 19. Horace Bristol, Homeward Bound, 1943, Gelatin silver print, 59.9 x $49.5 \mathrm{~cm}$, The Edward Steichen Naval Aviation Photographic Unit Collection, 974:0255:0019.
Fig. 18. Paul Dorsey, Tarawa, 1943,

Gelatin silver print, $27.3 \times 34.3 \mathrm{~cm}$, The Edward Steichen Naval Aviation Photographic Unit Collection, 974:0255:0026. 
Appendix B: Filemaker Database

*PDF of database submitted in a separate file 


\section{-Appendix C: Collection Description for the Ransom Center's Digital Collections Page}

The description I wrote to introduce the collection on the Digital Collections page on the Ransom Center's website is provided below:

The Edward Steichen Naval Aviation Photographic Unit Collection consists of 172 gelatin silver photographs taken by the Naval Aviation Photographic Unit during World War II under Edward Steichen's leadership. The Ransom Center's collection derives from the 8,000 photographs taken by the unit that remained in Edward Steichen's personal collection after the war. Upon Steichen's death in 1973, Tom Maloney, the publisher of U.S. Camera magazine and a close friend, was asked by Steichen's widow Joanna to distribute his collection to whatever institutions that Maloney decided upon.

The prints in the collection span 1942-1945, and depict scenes from some of the most intense fighting in the Pacific during World War II. The subjects represented in the collection include: portraits of officers and sailors, combat photographs, scenes from the daily life of sailors, and images of naval airplanes and aircraft carriers. The unit was assembled in 1942 and was led by the veteran photographer Edward Steichen for the remainder of the war. Originally commissioned by the U.S. Navy to take photographs for recruitment and training purposes, the unit progressively took on more of a documentary role and came to be known as the preeminent combat photography unit in the Navy. Steichen handpicked photographers for his unit with backgrounds in a variety of fields like advertising, magazines, newspapers, portraiture, and motion pictures in the hopes of producing images of the war from several distinct perspectives. The first photographers in the unit were Edward Steichen, Horace Bristol, Charles Fenno Jacobs, Victor Jorgensen, Charles Kerlee, and Wayne Miller, and Alfonso Iannelli, all of whom are represented in the collection.

The Edward Steichen Naval Aviation Photographic Unit Collection presents a valuable opportunity to introduce a new audience to the historically significant work of the Naval Aviation Photographic Unit. 
